\title{
The influence of oxime stereochemistry in the generation of nitrones from $\omega$-alkenyloximes by cyclization or 1,2-prototropy
}

\author{
Frances Heaney * and Colm O’Mahony \\ Department of Chemistry, University College, Galway, Ireland
}

Thermally induced cyclization of the anti-alkenyl oximes $E-7 \mathbf{a}, \mathbf{b}$ and $E-17 \mathbf{a}, \mathbf{b}$ affords cyclic $\alpha$-alkoxycarbonylnitrones 8 and the 6,7-bicyclic nitrones 18, respectively. The $s y n$-oximes $Z-7 \mathrm{~b}$ and $Z-17 \mathrm{~b}$ react via an alternate pathway to give exclusively the fused isoxazolidine derivatives $10 \mathrm{~b}$ and $19 \mathrm{~b}$, respectively. These oximes are configurationally stable at high temperatures with the energy barrier to isomerization being significantly greater than that to cyclization/cycloaddition. Neither the tert-butyl derivative 7c nor the $\varepsilon$-alkenyl oxime 7d share this characteristic and in these cases the products of thermal activation are independent of the geometry of the starting oxime. For $7 \mathrm{c}$ the energy barriers to oxime rotation and cyclization or cycloaddition are sufficiently close to allow all three reactions to proceed. With 7d, cis-trans isomerization and cyclization are the only observed reactions.

\section{Introduction}

The 1,3-dipolar cycloaddition can accomplish the synthesis of a range of highly functionalised stereochemically complex fivemembered rings. The isoxazolidines/isoxazolines which are the primary adducts from reaction between nitrones and alkenes/ alkynes have a labile $\mathrm{N}-\mathrm{O}$ bond easily cleaved under reductive or oxidative conditions, consequently this reaction is often used as a key step in targeted syntheses. ${ }^{1}$ The most general methods for nitrone preparation include oxidation of secondary amines (useful for the preparation of both cyclic and acyclic nitrones) ${ }^{2}$ and condensation between an $\mathrm{N}$-substituted hydroxylamine and a carbonyl compound. ${ }^{3}$ Many nitrones are isolable, stable compounds especially those with a $C$-aryl substituent and in the absence of any stabilizing substituent the nitrone may dimerize or trimerize and so may be best generated in situ. In a recent communication we have described the preparation of highly functionalized cyclic nitrones from alkenyl oximes. ${ }^{4}$

$\omega$-Alkenyloximes may form nitrones by one of two routes; they may tautomerize to form an acyclic NH-nitrone 1, the dipolar structure represents the less stable tautomer and to date no examples of the unsubstituted dipole have been isolated, their existence being substantiated through the formation of an intramolecular cycloaddition product $2 .^{5}$ This tandem process has been named the intramolecular oxime olefin cycloaddition reaction (IOOC) [Scheme 1(a)]. ${ }^{5 c}$ Secondly alkenyloximes may

(a)
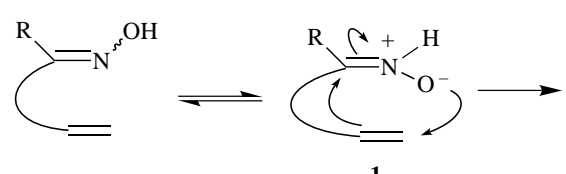

(b)

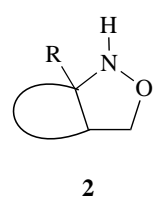

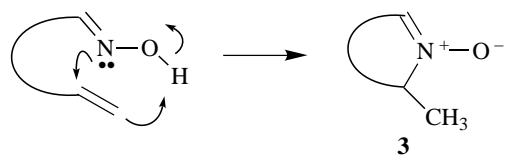

deficient), ${ }^{5 b, 6 a}$ unassisted cyclization is much less common ${ }^{5 b, 6 b, 6 c}$ and to date has generally involved only aldoximes [Scheme $1(b)]^{5 b, 6 c}$ Alkynylhydroxylamines 4 undergo a related pericyclic reaction effective for the formation of 5-, 6- and 7-membered cyclic nitrones 5. An initial ene-like cyclization (reverse Cope elimination $)^{7}$ is followed by proton transfer and tautomerism (Scheme 2). ${ }^{7 a}$ In the current example the $\mathrm{N}-\mathrm{O}-\mathrm{H}$ unit of the

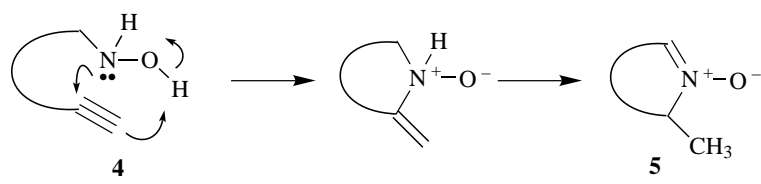

Scheme 2 Dipole formation from alkynylhydroxylamines

oxime adds across the internal $\mathrm{C}=\mathrm{C}$ double bond in a concerted fashion giving the cyclic dipole. For certain oximes the two modes of reactivity illustrated in Scheme 1 are in competition and the preferred reaction path in any given case will be that of lowest energy.

\section{Results and discussion}

The oximes 7 were prepared in two steps from their parent $\alpha$-keto acids; esterification with the corresponding alcohol proceeded in high yield to give the $\alpha$-oxo esters 6 which were converted to the oximes 7 following reaction with hydroxylamine (Tables 1 and 2). Transformation of $\mathbf{6 a}$ gave a single diastereoisomer $E-7 \mathbf{a}(65 \%)$ whilst $\mathbf{6 b , c , d}$ each gave both<smiles>[R]C(=O)C(=O)O[X]C=C</smiles><smiles></smiles>

E-7<smiles>[X]C=COC(=O)C([R])=[N+]([14CH3])O</smiles>

Z-7

$$
\begin{aligned}
& \text { a } \mathrm{R}=\mathrm{Me}, \mathrm{X}=\mathrm{CH}_{2} \\
& \text { b } \mathrm{R}=\mathrm{Ph}, \mathrm{X}=\mathrm{CH}_{2} \\
& \text { c } \mathrm{R}=\mathrm{Ph}, \mathrm{X}=\mathrm{CHBu}^{t} \\
& \text { d } \mathrm{R}=\mathrm{Ph}, \mathrm{X}=\mathrm{CH}_{2} \mathrm{CH}_{2}
\end{aligned}
$$

anti and syn isomers, with the $E$ - and $Z$-isomers being easily separated by flash chromatography. Oxime stereochemical assignment can be made in a number of ways; by ${ }^{1} \mathrm{H}$ NMR undergo an intramolecular cyclization reaction [1,3-azaprotio cyclotransfer (APT) $]^{5 b}$ forming the cyclic nitrone 3 . Numerous examples exist where the olefinic moiety is activated (electron 
Table 1 Selected UV-Visible and ${ }^{13} \mathrm{C}$ NMR data for the oximes 7

\begin{tabular}{llll}
\hline & \multicolumn{2}{l}{$\lambda_{\max } / \mathrm{nm}$} & \\
\cline { 2 - 3 } Compound & $\mathrm{MeOH}$ & $0.03 \%$ Methanolic $\mathrm{NaOH}$ & $\begin{array}{l}{ }^{13} \mathrm{C} \text { NMR resonance } \\
\text { of imino carbon atom }(\delta / \mathrm{ppm})^{a}\end{array}$ \\
\hline$E-7 \mathbf{a}$ & 221.77 & 260.11 & 149.2 \\
$E-7 \mathbf{b}$ & $243.44,233.44,218.43$ & $273.44,243.44,225.11$ & 151.6 \\
$Z-7 \mathbf{b}$ & 209.45 & 210.11 & 149.6 \\
$E-7 \mathbf{c}$ & - & - & 151.4 \\
$Z-7 \mathbf{c}$ & - & $273.44,225.11,206.78$ & 148.7 \\
$E-7 \mathbf{d}$ & $243.44,208.44$ & $256.78,208.44$ & 149.8 \\
$Z-7 \mathbf{7 d}$ & $250.10,213.44$ & & \\
\hline
\end{tabular}

${ }^{a 13} \mathrm{C}$ NMR spectra were taken in $\mathrm{CDCl}_{3}$.

Table 2 Analytical data for the $\alpha$-oxo esters $\mathbf{6}$ and $\mathbf{1 6}$ and the corresponding oximes $\mathbf{7}$ and $\mathbf{1 7}$

\begin{tabular}{|c|c|c|c|c|c|c|}
\hline & & & & $\mathrm{C}$ & $\mathrm{H}$ & $\mathrm{N}$ \\
\hline Compound & $\begin{array}{l}\text { Molecular } \\
\text { formula }\end{array}$ & $\begin{array}{l}\text { Yield } \\
(\%)\end{array}$ & Physical properties & $\begin{array}{l}\text { Found }(\%) \\
\text { (Requires) }\end{array}$ & & \\
\hline $6 \mathbf{b}$ & $\mathrm{C}_{11} \mathrm{H}_{10} \mathrm{O}_{3}$ & 81 & bp: $126-128^{\circ} \mathrm{C}, 0.1 \mathrm{mmHg}$ & $\begin{array}{c}69.19 \\
(69.47)\end{array}$ & $\begin{array}{c}5.40 \\
(5.26)\end{array}$ & $\begin{array}{c}0 \\
(0)\end{array}$ \\
\hline 6d & $\mathrm{C}_{12} \mathrm{H}_{12} \mathrm{O}_{3}$ & 90 & bp: $90-94{ }^{\circ} \mathrm{C}, 0.3 \mathrm{mmHg}$ & $\begin{array}{c}70.37 \\
(70.59)\end{array}$ & $\begin{array}{c}5.94 \\
(5.88)\end{array}$ & $\begin{array}{c}0 \\
(0)\end{array}$ \\
\hline $16 \mathbf{a}$ & $\mathrm{C}_{11} \mathrm{H}_{12} \mathrm{O}_{2}$ & 85 & $\begin{array}{l}\text { bp: } 93-95^{\circ} \mathrm{C}, 2.0 \mathrm{mmHg} \\
\text { mp: } 29-30^{\circ} \mathrm{C}\end{array}$ & $\begin{array}{l}75.21 \\
(75.00)\end{array}$ & $\begin{array}{c}6.84 \\
(6.82)\end{array}$ & $\begin{array}{c}0 \\
(0)\end{array}$ \\
\hline $16 b$ & $\mathrm{C}_{16} \mathrm{H}_{14} \mathrm{O}_{2}$ & 90 & bp: $110-112^{\circ} \mathrm{C}, 0.03 \mathrm{mmHg}$ & $\begin{array}{c}80.54 \\
(80.67)\end{array}$ & $\begin{array}{c}5.72 \\
(5.88)\end{array}$ & $\begin{array}{c}0 \\
(0)\end{array}$ \\
\hline $\begin{array}{l}Z-7 \mathbf{b} \\
E-7 \mathbf{b}\end{array}$ & $\mathrm{C}_{11} \mathrm{H}_{11} \mathrm{NO}_{3}$ & $\begin{array}{l}38 \\
55\end{array}$ & $\begin{array}{l}\text { bp: } 110-112^{\circ} \mathrm{C}, 0.5 \mathrm{mmHg} \\
\text { mp: } 90-94^{\circ} \mathrm{C} \text { (benzene-pet. spirit) }\end{array}$ & $\begin{array}{c}64.17 \\
(64.39)\end{array}$ & $\begin{array}{c}5.07 \\
(5.37)\end{array}$ & $\begin{array}{c}6.84 \\
(6.87)\end{array}$ \\
\hline$Z-7 \mathrm{c}$ & $\mathrm{C}_{15} \mathrm{H}_{19} \mathrm{NO}_{3}$ & 45 & $R_{\mathrm{f}} 0.48\left(\mathrm{Et}_{2} \mathrm{O}\right.$-pet. spirit, $\left.1: 4\right)$ & 69.08 & 7.32 & $5.33^{a}$ \\
\hline$E-7 \mathrm{c}$ & & 20 & mp: $110-111^{\circ} \mathrm{C}$ (benzene-pet. spirit) & $(68.97)$ & (7.28) & (5.36) \\
\hline$Z-7 \mathbf{d}$ & $\mathrm{C}_{12} \mathrm{H}_{13} \mathrm{NO}_{3}$ & 49 & bp: $138^{\circ} \mathrm{C}, 0.025 \mathrm{mmHg}$ & 65.48 & 5.67 & $6.21^{a}$ \\
\hline$E-7 \mathbf{d}$ & & 47 & $\mathrm{mp}: 46-48^{\circ} \mathrm{C}$ (benzene-pet. spirit) & $(65.75)$ & $(5.94)$ & $(6.39)$ \\
\hline$E-17 \mathbf{a}$ & $\mathrm{C}_{11} \mathrm{H}_{13} \mathrm{NO}_{2}$ & 94 & mp: $69-71{ }^{\circ} \mathrm{C}$ (benzene-pet. spirit) & $\begin{array}{c}69.33 \\
(69.11)\end{array}$ & $\begin{array}{l}7.08 \\
(6.81)\end{array}$ & $\begin{array}{r}7.59 \\
(7.33)\end{array}$ \\
\hline $\begin{array}{l}Z-17 \mathbf{b} \\
E-17 \mathbf{b}\end{array}$ & $\mathrm{C}_{16} \mathrm{H}_{15} \mathrm{NO}_{2}$ & $\begin{array}{l}70 \\
23\end{array}$ & $\begin{array}{l}\mathrm{mp}: 100-101^{\circ} \mathrm{C} \text { (benzene-hexane) } \\
\text { mp: } 123-124^{\circ} \mathrm{C} \text { (benzene-hexane) }\end{array}$ & $\begin{array}{l}75.77 \\
(75.89)\end{array}$ & $\begin{array}{c}6.04 \\
(5.93)\end{array}$ & $\begin{array}{r}5.81^{a} \\
(5.53)\end{array}$ \\
\hline
\end{tabular}

${ }^{a}$ Microanalytical data reported for the major oxime isomer only; satisfactory data have also been obtained for the minor isomer.

utilization of through-space effects, ${ }^{8}$ by ${ }^{13} \mathrm{C}$ or ${ }^{15} \mathrm{~N}$ NMR spectra studies, ${ }^{9}$ and by examination of $J_{{ }^{13} \mathrm{C},{ }^{1} \mathrm{H}}$ coupling constants for aldoximes. ${ }^{10}$ In this case assignment was based largely on UV $\pi \rightarrow \pi^{*}$ absorption; (E)-1,2-hydroxyiminoketones are known to exhibit a bathochromic shift when their spectra, recorded in basic solution $(\mathrm{MeOH}-\mathrm{NaOH})$, are compared with those measured in neutral solution $(\mathrm{MeOH})$, whereas $Z$-isomers show no such effect. ${ }^{11}$ The anti oximes $E-7 \mathbf{a}, \mathbf{b}, \mathbf{c}$, showed a shift of ca. $30 \mathrm{~nm}$ under these conditions whilst the $s y n$-isomers $Z-7 \mathbf{b}, \mathbf{c}$ showed very little change. Additionally in each case the ${ }^{13} \mathrm{C}$ resonance signal for the hydroxyimino carbon atom for the $E$-isomers appeared downfield of the corresponding signal for the $Z$-isomers. Finally irradiation of the hydroxyimino proton gave a positive enhancement on to the $\mathrm{C} \alpha$-substituent in the $E$-oxime series whilst no effect was observed with the $Z$-isomers (Table 1).

The propensity for (E)-prop-2-enyl 2-(hydroxyimino)propanoate to behave as a dipole precursor was investigated: heating a solution of $E-7 \mathbf{a}$ in each of $\mathrm{MeOH}, \mathrm{DMF}$ or $\mathrm{C}_{6} \mathrm{H}_{6}$ at reflux temperature resulted only in returned starting material. In boiling xylene reaction was slow, however heating in boiling mesitylene effected complete conversion of the substrate to products. The dipole $\mathbf{8 a}$ was isolated in $85 \%$ yield and mixed isomers of the dimeric compounds $9 \mathbf{a}$ in $5 \%$ yield. None of the alternative bicyclic furoisoxazolone 10a was detected. 1,3Oxazolin-5-one 3-oxides 11, the 5-ring analogues of $\mathbf{8}$, have been generated from reaction of isonitroso Meldrum's acid with various ketones. ${ }^{12}$

The separated oxime isomers $E$ - and $Z$-7b were independently heated in boiling xylene. After $30 \mathrm{~h}$ the anti-oxime $E-\mathbf{7 b}$ had reacted exclusively in a 6-exo-trig cyclization affording $\mathbf{8 b}$ in $85 \%$ yield whilst the syn-oxime $Z$-7b reacted more slowly<smiles>[R]C1=[N+]([O-])C(C)[C@]([14CH3])([125I])OC1=O</smiles>

8a $\mathrm{R}=\mathrm{Me}$ b $\mathrm{R}=\mathrm{Ph}$<smiles>[R]C(=NO)C(=O)OCC1CC2([R])ON1[C@@H](C)C([14CH3])([14CH3])OC2=O</smiles>

9a $\mathrm{R}=\mathrm{Me}$ b $\mathrm{R}=\mathrm{Ph}$<smiles>[Y9]OC([R])C1CC(C(=O)OC)(c2ccccc2)N(C(C)C([R])C)O1</smiles>

9c $\mathrm{R}=\mathrm{Bu}^{t}, n=0$

9d $\mathrm{R}=\mathrm{H}, n=1$<smiles>[R][C@]12NOC[C@H]1COC2=O</smiles>

10a $\mathrm{R}=\mathrm{Me}$

b $\mathrm{R}=\mathrm{Ph}$<smiles>[R]C1([R])OC(=O)C=[N+]1[O-]</smiles>

11

yielding the furoisoxazolone $\mathbf{1 0 b}(70 \%$ conversion of starting material after $36 \mathrm{~h}$ ) (Tables 3 and 4). Evidently each oxime is geometrically stable under the reaction conditions and the $Z$-isomer reacts only by path $(a)$, whilst the $E$-oxime reacts specifically via path $(b)$, Scheme 1 . That oxime geometry may have a defining influence on reactivity has been observed in many cases, ${ }^{13}$ for example in a recent report Tiecco et al. have shown that, depending on its geometry, the oxime group can act as either an oxygen or a nitrogen nucleophile in the intra- 


\begin{tabular}{|c|c|c|c|c|c|c|}
\hline & & & & $\mathrm{C}$ & $\mathrm{H}$ & $\mathrm{N}$ \\
\hline Compound & $\begin{array}{l}\text { Molecular } \\
\text { formula }\end{array}$ & $\begin{array}{l}\text { Yield } \\
(\%)\end{array}$ & Physical properties & $\begin{array}{l}\text { Found }(\%) \\
\text { (Requires) }\end{array}$ & & \\
\hline $8 \mathbf{a}$ & $\mathrm{C}_{6} \mathrm{H}_{9} \mathrm{NO}_{3}$ & 85 & bp: $115-120^{\circ} \mathrm{C}, 0.5 \mathrm{mmHg}$ & $\begin{array}{c}50.20 \\
(50.35)\end{array}$ & $\begin{array}{c}6.44 \\
(6.34)\end{array}$ & $\begin{array}{c}9.67 \\
(9.79)\end{array}$ \\
\hline $8 b$ & $\mathrm{C}_{11} \mathrm{H}_{11} \mathrm{NO}_{3}$ & 85 & $\mathrm{mp}: 94-95^{\circ} \mathrm{C}$ (benzene-pet. spirit) & $\begin{array}{c}64.56 \\
(64.68)\end{array}$ & $\begin{array}{c}5.37 \\
(5.35)\end{array}$ & $\begin{array}{l}6.83 \\
(6.78)\end{array}$ \\
\hline $8 c$ & $\mathrm{C}_{15} \mathrm{H}_{19} \mathrm{NO}_{3}$ & 33 & $\mathrm{mp}: 93-95^{\circ} \mathrm{C}$ (benzene-pet. spirit) & $\begin{array}{c}69.07 \\
(68.97)\end{array}$ & $\begin{array}{c}7.34 \\
(7.28)\end{array}$ & $\begin{array}{c}5.49 \\
(5.36)\end{array}$ \\
\hline 8d & $\mathrm{C}_{12} \mathrm{H}_{13} \mathrm{NO}_{3}$ & 32 & mp: $105-107^{\circ} \mathrm{C}$ (benzene-pet. spirit) & $\begin{array}{c}65.56 \\
(65.75)\end{array}$ & $\begin{array}{c}6.04 \\
(5.94)\end{array}$ & $\begin{array}{c}6.21 \\
(6.39)\end{array}$ \\
\hline $18 \mathbf{a}$ & $\mathrm{C}_{11} \mathrm{H}_{13} \mathrm{NO}_{2}$ & 98 & bp: $119-123^{\circ} \mathrm{C}, 0.6 \mathrm{mmHg}$ & $\begin{array}{c}68.91 \\
(69.11)\end{array}$ & $\begin{array}{c}6.74 \\
(6.81)\end{array}$ & $\begin{array}{c}7.54 \\
(7.33)\end{array}$ \\
\hline $18 b$ & $\mathrm{C}_{16} \mathrm{H}_{15} \mathrm{NO}_{2}$ & 92 & mp: $119-120^{\circ} \mathrm{C}$ (benzene-pet. spirit) & $\begin{array}{c}75.79 \\
(54.77)\end{array}$ & $\begin{array}{c}5.77 \\
(6.22)\end{array}$ & $\begin{array}{c}5.63 \\
(5.53)\end{array}$ \\
\hline
\end{tabular}

Table 4 Analytical data for the isoxazolo-fused adducts $\mathbf{1 0}$ and $\mathbf{1 9}$

\begin{tabular}{|c|c|c|c|c|c|c|}
\hline & & & & $\mathrm{C}$ & $\mathrm{H}$ & $\mathrm{N}$ \\
\hline Compound & $\begin{array}{l}\text { Molecular } \\
\text { formula }\end{array}$ & $\begin{array}{l}\text { Yield } \\
(\%)\end{array}$ & $\mathrm{mp} /{ }^{\circ} \mathrm{C}^{a}$ & $\begin{array}{l}\text { Found }(\%) \\
\text { (Requires) }\end{array}$ & & \\
\hline $10 \mathrm{a}$ & $\mathrm{C}_{6} \mathrm{H}_{9} \mathrm{NO}_{3}$ & 4 & $80-81$ & $\begin{array}{c}50.43 \\
(50.35)\end{array}$ & $\begin{array}{c}6.44 \\
(6.34)\end{array}$ & $\begin{array}{l}10.02 \\
(9.79)\end{array}$ \\
\hline $10 b$ & $\mathrm{C}_{11} \mathrm{H}_{11} \mathrm{NO}_{3}$ & 66 & $133-136$ & $\begin{array}{c}64.66 \\
(64.39)\end{array}$ & $\begin{array}{c}5.15 \\
(5.37)\end{array}$ & $\begin{array}{c}6.68 \\
(6.83)\end{array}$ \\
\hline $10 \mathrm{c}$ & $\mathrm{C}_{15} \mathrm{H}_{19} \mathrm{NO}_{3}$ & 7 & $136-137$ & $\begin{array}{c}68.99 \\
(68.97)\end{array}$ & $\begin{array}{c}7.44 \\
(7.28)\end{array}$ & $\begin{array}{c}5.29 \\
(5.36)\end{array}$ \\
\hline $19 b$ & $\mathrm{C}_{16} \mathrm{H}_{15} \mathrm{NO}_{2}$ & 58 & $110-112$ & $\begin{array}{c}75.69 \\
(75.89)\end{array}$ & $\begin{array}{c}5.66 \\
(5.93)\end{array}$ & $\begin{array}{c}5.34 \\
(5.53)\end{array}$ \\
\hline
\end{tabular}

${ }^{a}$ From benzene-pet. spirit.

molecular selenium-induced cyclizations of $\alpha$-alkenyloximes generating 1,2-oxazines or cyclic nitrones respectively, ${ }^{13 a}$ and Noguchi's group have demonstrated that only the $E$-oxime ethers 12 participate in an intramolecular azepine-forming

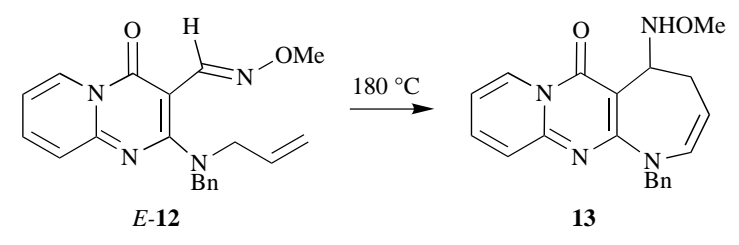

reaction whilst $Z$-isomers remain unchanged under the same experimental conditions. ${ }^{13 b}$

In an effort to probe the generality of the reaction $(E-7 \rightarrow \mathbf{8}$ and $Z-7 \rightarrow \mathbf{1 0}$ ) and in particular its tolerance to substitution and ring size the oximes $\mathbf{7 c , d}$ were prepared. It was anticipated that the introduction of a tert-butyl substituent on the alkenyl chain in the oximes $\mathbf{7 c}$ may invoke diastereoselectivity in both the APT reaction (leading to $\mathbf{8 c}$ ) and in the IOOC reaction (leading to 10c). The separated oxime isomers $E-7 \mathbf{c}$ and $Z-7 \mathbf{c}$

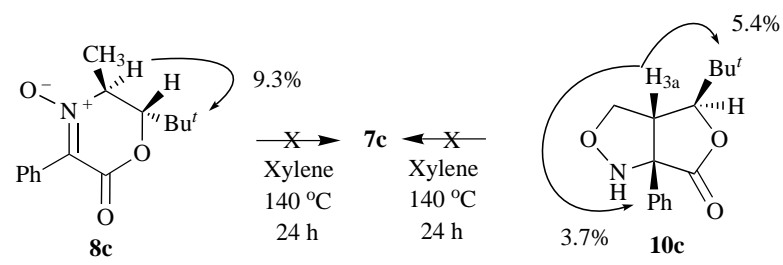

were heated in boiling xylene and the following points noted (i) the isomers were shown to be devoid of thermal stability and (ii) in each case reaction was slower than that observed for the unsubstituted analogue $\mathbf{7 b}$. Following the heating of $E-7 \mathrm{c}$ the reaction products comprised a $5: 3: 1: 5$ mixture of the syn-oxime $Z-7 \mathbf{c}$, returned anti-oxime $E-7 \mathbf{c}$, furoisoxazolone $10 \mathrm{c}$ and the cyclic dipole $8 \mathbf{c}$. The same products were obtained in a $4: 1: 1: 2$ ratio following reaction with the $Z$-oxime $Z$-7c. That oxime interconversion occurs directly rather than by retrocyclization of the dipole $\mathbf{8 c}$ is evident from the thermal stability of the latter which remains unchanged after heating in boiling xylene for $24 \mathrm{~h}$. The cycloadduct 10c is also stable under these reaction conditions. Significantly the cyclization and cycloaddition products are formed diastereospecifically; for the dipole 8c NOEDS studies indicate the methyl and tert-butyl substituents are trans orientated while for the cycloadduct 10c irradiation of the $\mathrm{H}^{3 \mathrm{a}}$ proton causes an enhancement on the cross-ring $o$-Ar protons $(3.7 \%)$ and on the tertbutyl group $(5.4 \%)$ indicating it has a cis relationship to both substituents.

The 7-exo-trig cyclization is also an allowed process ${ }^{14}$ and we envisaged that the $E$-isomer of the $\varepsilon$-alkenyl oxime 7 d may cyclize to the 7 -membered oxazepinone $N$-oxide 8d. Indeed 7-membered nitrones have been prepared by Holmes and coworkers by cyclization of alk-6-ynylhydroxylamines by the general mechanism outlined in Scheme 2. ${ }^{7 a}$ Following heating of $E-7 \mathbf{d}$ in refluxing xylene, 8d was formed in $32 \%$ yield with unreacted oxime present as a 1:1.1 mixture of $E$ - and $Z$-isomers, and a trace amount of the dimeric adducts 9d accounting for the rest of the reaction material. The low yield of dipole may be attributed to a combination of the following; the increased entropy of activation required for the formation of a 7-membered ring, the reversible nature of dipole formation and/or the influence of the allyl- and butenyl-oxycarbonyl group on the relative reactivity of the olefinic centres in $7 \mathbf{b}$ and 7d. In contrast to the stability of the 6-membered dipole 8c, simply heating a solution of $\mathbf{8 d}$ in boiling mesitylene generated a $1: 2$ ratio of the isomeric oximes $E$ - and $Z-7 \mathbf{d}$. When the $s y n-$ oxime $Z$-7d was heated in boiling xylene the reaction products comprised unreacted oxime ( $75 \%)$, as a $2: 5$ mixture of $E$ - and $Z$-isomers, and the cyclic dipole $\mathbf{8 d}(15 \%)$; none of the antici- 
<smiles></smiles>

8d

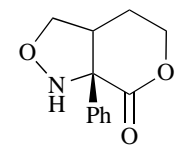

$10 d$ pated pyranoisoxazolone 10d resulted. Clearly both oximes $E$ - and $Z$-7d suffer partial isomerization under the reaction conditions studied. The failure of $Z$-7d to partake in the IOOC reaction sequence is consistent with Hassner's observations that whilst the unsaturated aldoximes 14a underwent smooth trans-

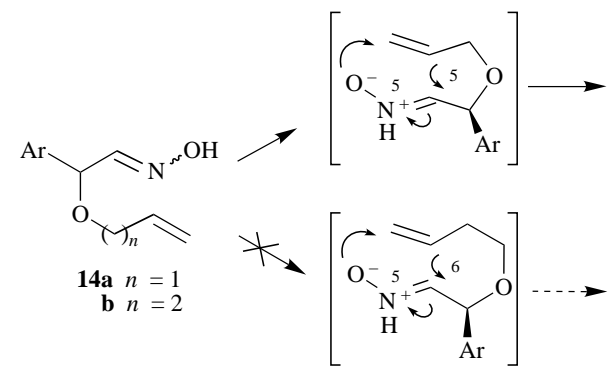<smiles>[Y19]C1OCC2CONC2C1[Al]</smiles>

formation to the furoisoxazoles $15 \mathrm{a}$ the homologous $14 \mathrm{~b}$ failed to form the corresponding pyranoisoxazoles $\mathbf{1 5 b}$ under the same experimental conditions. ${ }^{5 d}$ These results suggest that the transition state required for the formation of the 6,5-bicyclic skeleton is more difficult to attain than the corresponding 5,5skeleton. That this difficulty can be overcome by judicious positioning of the aldoxime and alkene functions is suggested from Oppolzer's observation that 2-allyloxybenzaldehyde oxime participates in an IOOC reaction giving the 6,6,5-tricycle $19 c^{5 g}$

In an effort to facilitate the 7-exo-trig cyclization the $\varepsilon$-alkenyl oximes 17 were prepared. By reducing the flexibility of the tether uniting the oxime with the olefinic moiety these reacting centres should more easily adopt the transition state required for intramolecular cyclization - the aryl ring in $\mathbf{1 7}$ may therefore be described as a steric buttress. ${ }^{15}$ Allyl bromide condenses with $o$-hydroxyacetophenone and $o$-hydroxybenzophenone to give the alkenyl ethers 16; oximation of 16a yielded $E-17$ a as a single stereoisomer whilst $\mathbf{1 6 b}$ reacted to give a $1: 3$ mixture of the $E$ - and $Z$-isomers of $\mathbf{1 7} \mathbf{b}$. Configurational assignment of $E-\mathbf{1 7 a}$ is based on a $9.8 \%$ enhancement on the $o$-Ar-H signal upon irradiation of the hydroxy proton, the

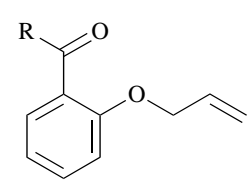

16a $\mathrm{R}=\mathrm{Me}$ b $\mathrm{R}=\mathrm{Ph}$

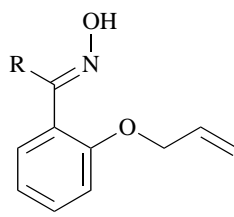

$E$-17a $\mathrm{R}=\mathrm{Me}$

b $\mathrm{R}=\mathrm{Ph}$<smiles>C=CCOc1ccccc1/C(=N\O)c1ccccc1</smiles>

$Z-17 b$ geometrical isomers $E \mathbf{- 1 7} \mathbf{b}$ and $Z \mathbf{- 1 7 b}$ are distinguished on the basis of their ${ }^{13} \mathrm{C}$ NMR data with the $E$-isomer having the more downfield imino carbon signal $\left(\mathrm{CDCl}_{3}, 155.7\right.$ vs. 158.6 ppm).

The oxime $E$-17a underwent quantitative conversion to the 6,7-bicyclic dipole 18a following heating $(14 \mathrm{~h})$ in boiling xylene, $E-\mathbf{1 7 b}$ reacted similarly giving $\mathbf{1 8 b}$ after just $5 \mathrm{~h}$ heating. Clearly the incorporation of the aryl ring in the chain linking the oxime to the alkene significantly reduces the conformational mobility of the reacting centres in E-17 making dipole formation facile compared to that previously observed with the open chain substrate $E$-7d. The $s y n$-oxime $Z$-17b also reacted in a chemospecific manner and after $50 \mathrm{~h}$ heating in refluxing xylene the reaction products comprised the benzofuroisoxazole 19b<smiles>[R]C1=[N+]([O-])C(C)COc2ccccc21</smiles>

18a $\mathrm{R}=\mathrm{Me}$ c $\mathrm{R}=\mathrm{Ph}$

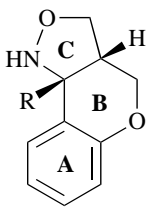

19a $\mathrm{R}=\mathrm{Me}$ b $\mathrm{R}=\mathrm{Ph}$
c $\mathrm{R}=\mathrm{H}$
$(58 \%)$ and unchanged oxime $(25 \%)$. The cycloadduct was obtained as a single diastereoisomer with cis stereochemistry at the $\mathrm{BC}$ ring junction assigned on the basis of NOEDS results.

\section{Conclusions}

In all the cyclization reactions hydroquinone $(1 \% \mathrm{w} / \mathrm{v})$ was added to the reaction solvent to prevent its decomposition on prolonged heating and since both the dipoles $(\mathbf{8}$ and 18$)$ and the cycloadducts (10 and 19) form in such high yields under these conditions a radical based reaction mechanism is not favoured in either reaction path (Scheme 1). Formation of the cyclic nitrones is via a concerted pericyclic mechanism and the antioxime isomers $E-\mathbf{7 a}, \mathbf{b}$ readily attain the necessary geometry for the 6,5-bicyclic transition state (Scheme 3), therefore the APT
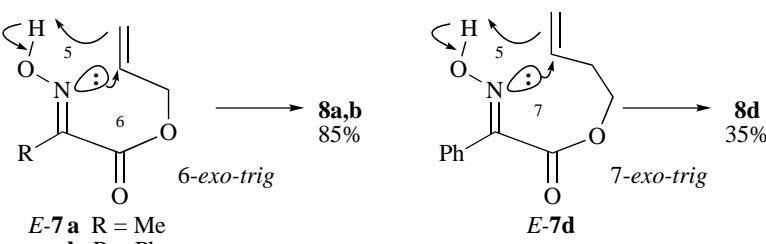

b $\mathrm{R}=\mathrm{Ph}$

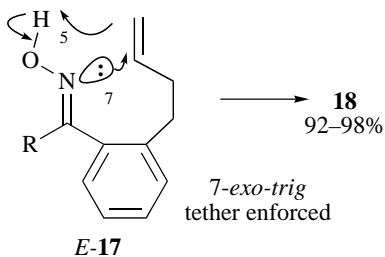

Scheme 3

reaction does not suffer competition from oxime isomerization or tautomerism to the corresponding $\mathrm{NH}$-dipole under the reaction conditions $\left(E_{\mathrm{a}} 1<E_{\mathrm{a}} 2\right.$, Scheme 4$)$. The oxime $E-7 \mathbf{c}$ on

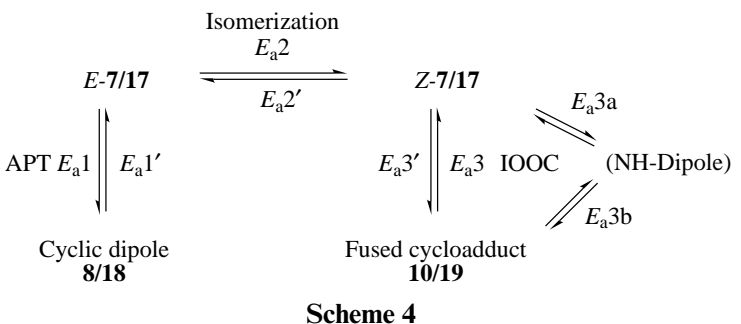

Scheme 4

the other hand with its bulky tert-butyl substituent displays remarkable sensitivity to substitution and oxime isomerization and cycloaddition (IOOC) compete effectively with the proposed APT reaction $\left(E_{\mathrm{a}} 1 \sim E_{\mathrm{a}} 2 \sim E_{\mathrm{a}} 3\right)$. In the case of the $\varepsilon$-alkenyl oxime $E$-7d a 7,5-bicyclic transition state must be reached to allow formation of the oxazepinone $N$-oxide $8 d$ (Scheme 3), this requirement places significant demands on the open chain structure and consequently dipole generation is accompanied by $E / Z$ oxime isomerization, however the $Z$-7d so 
formed is unable to undergo the IOOC reaction as the energy barrier to the formation of the 6,5-bicyclic adduct 10d is too great $\left(E_{\mathrm{a}} 1 \sim E_{\mathrm{a}} 2<E_{\mathrm{a}} 3\right)$. The conformationally constrained analogues $E-17$ more easily attain the necessary approach of reacting centres for the 7-exo-trig cyclization (Scheme 3) and they thermally cyclize to the corresponding benzoxazepine $N$-oxides 18 in excellent yield.

With the $s y n$-oxime isomers $Z-\mathbf{7 b}$ and $Z-\mathbf{1 7} \mathbf{b}$ attainment of the transition state for direct formation of cyclic dipoles is impossible to achieve. Therefore there are only two reaction paths available to these substrates viz. isomerization to the $E$-oxime (and then possible cyclization) or a tautomerism to the corresponding $\mathrm{NH}$-dipole and intramolecular cycloaddition (IOOC). The open chain $\delta$-alkenyl oxime $Z$-7b and the conformationally restricted $\varepsilon$-alkenyl oxime $Z$-17b reacted chemospecifically via the IOOC route giving single stereoisomeric isoxazolo fused adducts in each case, no oxime isomerization occurred $\left(E_{\mathrm{a}} 3<E_{\mathrm{a}} 2^{\prime}\right)$. On the contrary, the tert-butyl substituted $\delta$-alkenyl oxime $Z$-7c and the open chain $\varepsilon$-alkenyl oxime $Z$-7d suffered from facile oxime interconversion and when equilibrium had been reached the products from thermal activation of these syn-oximes were identical to those obtained from the corresponding anti-isomers under the same experimental conditions.

Interestingly, whilst an attempt to isomerize $E$-7a to the $Z$-isomer by heating in boiling water resulted in the loss of much of the reaction material, the furoisoxazolone 10a was isolated in small yield $(4 \%)$ together with unchanged starting oxime (16\%). Similar treatment of $E-7 \mathbf{b}$ gave the adduct $10 \mathrm{~b}$ in $67 \%$ yield together with both $E$ - and $Z$-oxime isomers (10 and $15 \%$, respectively). These observations suggest that oxime isomerization is more facile in water and indeed it has earlier been noted that the relative stability of iminoxyl radicals from benzaldehyde oxime shows a remarkable solvent dependency. ${ }^{16}$

The relatively slow rate of oxime isomerization compared with simple imines has recently been exploited in a study of the effect of $E / Z$ isomerization on the asymmetric hydrogenation of prochiral $\mathrm{C}=\mathrm{N}$ bonds. ${ }^{13 c}$ The enantioselectivity of the reaction was shown to reflect the $E / Z$ ratio of 1 -acetonaphthone oxime. The oximes $\mathbf{7}$ and $\mathbf{1 7}$ chosen in this study, like 1-acetonaphthone oxime, are conjugated ketoximes and therefore the barrier to rotation is expected to be high and the products of reaction likely to reflect the geometry of the starting oxime. In contrast the oximes 14 employed in Hassner's thermal IOOC study are all unconjugated aldoximes carrying a single substituent on the $\alpha$-carbon atom, the barrier to geometrical inversion would therefore be expected to be much lower thus explaining why in this case the products of reaction are independent of the stereochemistry of the starting oximes. ${ }^{5 c, d}$

Thermal cyclization of the conjugated $E$-alkenyl oximes $E-7 \mathbf{a}, \mathbf{b}$ and $E-\mathbf{1 7}$ provides easy access to geometry fixed $\alpha$-alkoxycarbonylnitrones $\mathbf{8}$ and benzoxazepine $N$-oxides $\mathbf{1 8}$, respectively. These interesting nitrones are reactive 1,3-dipoles and their cycloadditive behaviour will be discussed in a forthcoming paper.

\section{Experimental}

Melting points were determined on an Electrothermal melting point apparatus and are uncorrected. Elemental analyses were performed on a Perkin-Elmer model $240 \mathrm{CHN}$ analyser. ${ }^{1} \mathrm{H}$ NMR spectra were recorded using a JEOL EX90 FT NMR and a JEOL EX270 FT NMR spectrometer at probe temperatures with tetramethylsilane as internal reference and deuteriochloroform as solvent. $J$ Values are given in Hz. Flash column chromatography was carried out on silica gel 60 (Merck 9385, 70230 mesh, 40-60 mesh), analytical TLC plates were purchased from Merck. Samples were located by UV illumination using a portable Spectroline Hanovia lamp ( $\lambda 254 \mathrm{~nm}$ ) or by the use of iodine staining. All solvents used were purified by standard procedures and pet. spirit refers to that fraction of petroleum spirits boiling between $40-60{ }^{\circ} \mathrm{C}$.

\section{Prop-2-enyl benzoylformate $6 \mathrm{~b}$}

A solution of benzoylformic acid (4.0 g, $27 \mathrm{mmol})$, prop-2-en1-ol (2.35 g, $40 \mathrm{mmol})$ and a catalytic amount of toluene- $p$ sulfonic acid in benzene $\left(100 \mathrm{~cm}^{3}\right)$ was boiled in reflux $(16 \mathrm{~h})$ using a Dean-Stark apparatus. The reaction mixture was allowed to cool to room temp., washed firstly with sat. aq. $\mathrm{NaHCO}_{3}\left(2 \times 150 \mathrm{~cm}^{3}\right)$ and then $\mathrm{H}_{2} \mathrm{O}\left(150 \mathrm{~cm}^{3}\right)$. The organic layer was collected, dried $\left(\mathrm{Na}_{2} \mathrm{SO}_{4}\right)$ and concentrated to furnish the crude product as a yellow oil. Following fractional distillation the title compound was obtained as a colourless oil (4.1 $\mathrm{g}, 81 \%) . \delta_{\mathrm{H}} 4.87\left(\mathrm{~d}, 2 \mathrm{H}, \mathrm{OCH}_{2}\right), 5.40\left(\mathrm{~m}, 2 \mathrm{H}, \mathrm{CH}=\mathrm{CH}_{2}\right), 6.02$ $\left(\mathrm{m}, 1 \mathrm{H}, \mathrm{CH}=\mathrm{CH}_{2}\right), 7.50(\mathrm{t}, 2 \mathrm{H}, m-\mathrm{Ar}-\mathrm{H}), 7.65(\mathrm{t}, 1 \mathrm{H}, p-\mathrm{Ar}-\mathrm{H})$, $8.01(\mathrm{~d}, 2 \mathrm{H}, o-\mathrm{Ar}-\mathrm{H}) ; \delta_{\mathrm{C}} 66.2\left(\mathrm{OCH}_{2}\right), 119.5\left(\mathrm{CH}=\mathrm{CH}_{2}\right)$, $128.7(2 \times m$-Ar-C), $129.7(2 \times o$-Ar-C), 130.6 ( $p$-Ar-C), 133.1 $\left(\right.$ Ar-C), $134.7\left(\mathrm{CH}=\mathrm{CH}_{2}\right), 163.2(\mathrm{C}=\mathrm{O}$, ester $), 185.9(\mathrm{C}=\mathrm{O}$, ketone).

\section{4,4-Dimethylpent-1-en-3-yl benzoylformate $6 c$}

Benzoylformic acid (1.60 g, $11 \mathrm{mmol}), 4,4$-dimethylpent-1-en$3-\mathrm{ol}^{17}$ (1.48 g, $\left.13 \mathrm{mmol}\right)$ and a catalytic amount of toluene- $p$ sulfonic acid were stirred in benzene $\left(60 \mathrm{~cm}^{3}\right)$ at reflux using a Dean-Stark apparatus for $13 \mathrm{~h}$ (care was taken to ensure that the temperature of the oil bath did not rise above $100{ }^{\circ} \mathrm{C}$ ). The reaction mixture was allowed to cool to room temp. before washing firstly with sat. aq. $\mathrm{NaHCO}_{3}$ solution $\left(2 \times 100 \mathrm{~cm}^{3}\right)$ and then $\mathrm{H}_{2} \mathrm{O}\left(100 \mathrm{~cm}^{3}\right)$. After drying $\left(\mathrm{Na}_{2} \mathrm{SO}_{4}\right)$ the organic layer was concentrated to yield the crude product, a yellow oil $(2.04 \mathrm{~g}, 75 \%)$, which was used without further purification. (During the concentration step, the temperature of the water bath was not allowed to rise above $65^{\circ} \mathrm{C}$.) $\delta_{\mathrm{H}} 1.04(\mathrm{~s}, 9 \mathrm{H}$, $3 \times \mathrm{Me}), 4.83(\mathrm{~d}, 1 \mathrm{H}, \mathrm{OCH}, J 6.60), 5.50\left(\mathrm{~m}, 2 \mathrm{H}, \mathrm{CH}=\mathrm{CH} H_{2}\right)$, $5.90\left(\mathrm{~m}, 1 \mathrm{H}, \mathrm{CH}=\mathrm{CH}_{2}\right), 7.65-7.47(2 \times \mathrm{m}, 3 \mathrm{H}, 2 \times m$ and p-Ar-H), $7.99(\mathrm{~m}, 2 \mathrm{H}, o-\mathrm{Ar}-\mathrm{H}) ; \delta_{\mathrm{C}} 25.6(3 \times \mathrm{Me}), 34.4\left(\mathrm{CMe}_{3}\right)$, $66.2(\mathrm{OCH}), 119.5\left(\mathrm{CH}=\mathrm{CH}_{2}\right), 130.0-128.8(4 \times \mathrm{Ar}-\mathrm{C}), 134.8$ $\left(\mathrm{CH}=\mathrm{CH}_{2}\right), 163.6(\mathrm{C}=\mathrm{O}$, ester $), 186.6(\mathrm{C}=\mathrm{O}$, ketone $)$.

\section{But-3-enyl benzoylformate $6 \mathrm{~d}$}

A solution of benzoylformic acid $(11.80 \mathrm{~g}, 79 \mathrm{mmol})$, but-3-en$1-\mathrm{ol}(8.64 \mathrm{~g}, 120 \mathrm{mmol})$ and a catalytic amount of toluene- $p$ sulfonic acid in benzene $\left(325 \mathrm{~cm}^{3}\right)$ was boiled under reflux $(9 \mathrm{~h})$ using a Dean-Stark apparatus. The reaction mixture was allowed to cool to room temp., washed firstly with sat. aq. $\mathrm{NaHCO}_{3}\left(2 \times 100 \mathrm{~cm}^{3}\right)$ and then $\mathrm{H}_{2} \mathrm{O}\left(2 \times 100 \mathrm{~cm}^{3}\right)$. The organic layer was collected, dried $\left(\mathrm{Na}_{2} \mathrm{SO}_{4}\right)$ and concentrated to furnish the crude product as a yellow oil. Following fractional distillation, 6d was obtained as a colourless oil $(14.4 \mathrm{~g}, 90 \%) . \delta_{\mathrm{H}}$ $2.40\left(\mathrm{~m}, 2 \mathrm{H}, \mathrm{OCH}_{2} \mathrm{CH}_{2}\right), 4.38\left(\mathrm{t}, 2 \mathrm{H}, \mathrm{OCH}_{2}\right), 5.08(\mathrm{~m}, 2 \mathrm{H}$, $\left.\mathrm{CH}=\mathrm{CH}_{2}\right), 5.77\left(\mathrm{~m}, 1 \mathrm{H}, \mathrm{CH}=\mathrm{CH}_{2}\right), 7.39(\mathrm{t}, 2 \mathrm{H}, m-\mathrm{Ar}-\mathrm{H}), 7.59$ (t, $1 \mathrm{H}, p-\mathrm{Ar}-\mathrm{H}), 7.98(\mathrm{~d}, 2 \mathrm{H}, o-\mathrm{Ar}-\mathrm{H}) ; \delta_{\mathrm{C}} 32.5\left(\mathrm{OCH}_{2} \mathrm{CH}_{2}\right), 64.7$ $\left(\mathrm{OCH}_{2}\right), 117.5\left(\mathrm{CH}=\mathrm{CH}_{2}\right), 128.5(2 \times m-\mathrm{Ar}-\mathrm{C}), 129.6(2 \times$ $o$-Ar-C), 132.9 ( $p$-Ar-C), 134.5 (Ar-C), $134.6\left(C H=\mathrm{CH}_{2}\right), 163.2$ $(\mathrm{C}=\mathrm{O}$, ester $), 186.0(\mathrm{C}=\mathrm{O}$, ketone $)$.

\section{(E)-Prop-2-enyl 2-(hydroxyimino)propanoate $E$-7a}

The title compound was prepared according to literature procedure ${ }^{18}$ and was obtained as colourless plates $(5.11 \mathrm{~g}, 65 \%)$, $\operatorname{mp} 86^{\circ} \mathrm{C}$ (lit., ${ }^{18} 84-86{ }^{\circ} \mathrm{C}$ ).

\section{Prop-2-enyl 2-(hydroxyimino)-2-phenylacetate $\boldsymbol{Z}$-7b and $\boldsymbol{E}$-7b}

The $\alpha$-keto ester $\mathbf{6 b}(1.20 \mathrm{~g}, 6.3 \mathrm{mmol})$, hydroxylamine hydrochloride $(0.66 \mathrm{~g}, 9.5 \mathrm{mmol})$ and sodium acetate $(0.78 \mathrm{~g}, 9.5$ mmol) were stirred in $\mathrm{H}_{2} \mathrm{O}\left(50 \mathrm{~cm}^{3}\right)$ at $70^{\circ} \mathrm{C}$ for $14 \mathrm{~h}$. The reaction mixture was allowed to cool to room temp., and extracted with $\mathrm{CH}_{2} \mathrm{Cl}_{2}\left(2 \times 50 \mathrm{~cm}^{3}\right)$. The organic layers were combined, washed with $\mathrm{H}_{2} \mathrm{O}\left(2 \times 50 \mathrm{~cm}^{3}\right)$, dried $\left(\mathrm{Na}_{2} \mathrm{SO}_{4}\right)$ and concentrated to yield the crude products as a yellow gum. Separation by flash chromatography $\left(\mathrm{Et}_{2} \mathrm{O}\right.$ :pet. spirit, $\left.1: 2.2\right)$ 
gave the $s y n$-isomer $Z-7 \mathbf{b}$ a colourless oil $(0.49 \mathrm{~g}, 38 \%)$ and the anti-isomer $E-7 \mathbf{b}$ a white solid which crystallized to colourless needles $(0.71 \mathrm{~g}, 55 \%)$. Z-7b: $\delta_{\mathrm{H}} 4.89\left(\mathrm{~d}, 2 \mathrm{H}, \mathrm{OCH}_{2}\right), 5.35(\mathrm{~m}$, $\left.2 \mathrm{H}, \mathrm{CH}=\mathrm{CH}_{2}\right), 6.00\left(\mathrm{~m}, 1 \mathrm{H}, \mathrm{CH}=\mathrm{CH}_{2}\right), 7.39(\mathrm{~m}, 3 \mathrm{H}, \mathrm{Ar}-\mathrm{H})$, $7.57(\mathrm{~m}, 2 \mathrm{H}, 2 \times o-\mathrm{Ar}-\mathrm{H}), 8.64(\mathrm{br} \mathrm{s}, 1 \mathrm{H}, \mathrm{OH}) ; \delta_{\mathrm{C}} 66.4\left(\mathrm{OCH}_{2}\right)$ $119.6\left(\mathrm{CH}=\mathrm{CH}_{2}\right), 126.4$ (m-Ar-C), 128.8 (o-Ar-C), 130.5 ( $p$-Ar-C), 130.9 (Ar-C), $131.0\left(C H=\mathrm{CH}_{2}\right), 149.6(\mathrm{C}=\mathrm{N}), 163.4$ $(\mathrm{C}=\mathrm{O}) . E-7 \mathbf{b}: \delta_{\mathrm{H}} 4.77\left(\mathrm{~d}, 2 \mathrm{H}, \mathrm{OCH}_{2}\right), 5.29\left(\mathrm{~m}, 2 \mathrm{H}, \mathrm{CH}=\mathrm{CH}_{2}\right)$, $5.93\left(\mathrm{~m}, 1 \mathrm{H}, \mathrm{CH}=\mathrm{CH}_{2}\right), 7.44(\mathrm{~m}, 3 \mathrm{H}, \mathrm{Ar}-\mathrm{H}), 7.52(\mathrm{~m}, 2 \mathrm{H}, 2 \times$ $o$-Ar-H), $10.22(\mathrm{br} \mathrm{s}, 1 \mathrm{H}, \mathrm{OH}) ; \delta_{\mathrm{C}} 66.6\left(\mathrm{OCH}_{2}\right), 119.4$ $\left(\mathrm{CH}=\mathrm{CH}_{2}\right), 127.8$ (m-Ar-C), 128.1 (o-Ar-C), 128.6 ( $p$-Ar-C), $129.9(\mathrm{Ar}-\mathrm{C}), 131.4\left(\mathrm{CH}=\mathrm{CH}_{2}\right), 151.6(\mathrm{C}=\mathrm{N}), 163.2(\mathrm{C}=\mathrm{O})$.

\section{4,4-Dimethylpent-1-en-3-yl 2-(hydroxyimino)-2-phenylacetate $Z-7 \mathrm{c}$ and $E-7 \mathrm{c}$}

The $\alpha$-keto ester $\mathbf{6 c}(1.97 \mathrm{~g}, 8.0 \mathrm{mmol})$, hydroxylamine hydrochloride $(0.83 \mathrm{~g}, 12.0 \mathrm{mmol})$ and sodium acetate $(1.11 \mathrm{~g}, 13.50$ mmol) were stirred in $\mathrm{H}_{2} \mathrm{O}\left(60 \mathrm{~cm}^{3}\right)$ at $65^{\circ} \mathrm{C}$ for $25 \mathrm{~h}$. The reaction mixture was allowed to cool to room temp., before extracting with $\mathrm{CH}_{2} \mathrm{Cl}_{2}\left(4 \times 80 \mathrm{~cm}^{3}\right)$. The organic layers were combined, washed with water $\left(50 \mathrm{~cm}^{3}\right)$, dried $\left(\mathrm{Na}_{2} \mathrm{SO}_{4}\right)$ and concentrated to yield the crude products as a colourless gum. Purification by flash chromatography $\left(\mathrm{Et}_{2} \mathrm{O}\right.$ : pet. spirit, $\left.1: 6\right)$ gave recovered starting material $(0.59 \mathrm{~g}, 30 \%)$, syn-isomer $Z-7 \mathrm{c}$ a colourless oil $(0.93 \mathrm{~g}, 49 \%)$ and anti-isomer $E-7 \mathbf{c}$ a white solid which crystallized to colourless needles $(0.43 \mathrm{~g}, 20 \%) . Z-7 \mathrm{c}: \delta_{\mathrm{H}}$ $1.02(\mathrm{~s}, 9 \mathrm{H}, 3 \times \mathrm{Me}), 4.86(\mathrm{~d}, 1 \mathrm{H}, \mathrm{OCH}, J 6.59), 5.59(\mathrm{~m}, 1 \mathrm{H}$, $\left.\mathrm{CH}=\mathrm{CH}_{2}\right), 5.89\left(\mathrm{~d}, 2 \mathrm{H}, \mathrm{CH}=\mathrm{CH}_{2}, J 15.38\right), 7.39(\mathrm{~m}, 3 \mathrm{H}, m$ - and p-Ar-H), $7.55(\mathrm{~m}, 2 \mathrm{H}, o-\mathrm{Ar}-\mathrm{H}), 9.02(\mathrm{br} \mathrm{s}, 1 \mathrm{H}, \mathrm{OH}) ; \delta_{\mathrm{C}} 29.1$ $(3 \times \mathrm{Me}), 33.3\left(\mathrm{CMe}_{3}\right), 67.0(\mathrm{OCH}), 118.0\left(\mathrm{CH}=\mathrm{CH}_{2}\right), 130.2$ $126.6(4 \times \mathrm{Ar}-\mathrm{C}), 130.5\left(\mathrm{CH}=\mathrm{CH}_{2}\right), 148.7(\mathrm{C}=\mathrm{N}), 163.5(\mathrm{C}=\mathrm{O})$. $E-7 \mathrm{c}: \delta_{\mathrm{H}} 0.97(\mathrm{~s}, 9 \mathrm{H}, 3 \times \mathrm{Me}), 4.70(\mathrm{~d}, 1 \mathrm{H}, \mathrm{OCH}, J 6.59), 5.52$ $\left(\mathrm{m}, 1 \mathrm{H}, \mathrm{CH}=\mathrm{CH}_{2}\right), 5.81\left(\mathrm{~d}, 2 \mathrm{H}, \mathrm{CH}=\mathrm{CH}_{2}, J 15.39\right), 7.42(\mathrm{~m}$, $3 \mathrm{H}, m$ - and $p$-Ar-H), $7.52(\mathrm{~m}, 2 \mathrm{H}, o-\mathrm{Ar}-\mathrm{H}), 10.18$ (br s, $1 \mathrm{H}$, $\mathrm{OH}) ; \quad \delta_{\mathrm{C}} 29.3(3 \times \mathrm{Me}), \quad 34.0\left(\mathrm{CMe}_{3}\right), 67.3(\mathrm{OCH}), 118.0$ $\left(\mathrm{CH}=\mathrm{CH}_{2}\right), 129.9-128.1(4 \times \mathrm{Ar}-\mathrm{C}), 130.1\left(\mathrm{CH}=\mathrm{CH}_{2}\right), 151.4$ $(\mathrm{C}=\mathrm{N}), 163.6(\mathrm{C}=\mathrm{O})$.

\section{But-3-enyl 2-(hydroxyimino)-2-phenylacetate $\boldsymbol{Z}$-7d and $\boldsymbol{E}$-7d}

The $\alpha$-keto ester $\mathbf{6 d}(11.12 \mathrm{~g}, 55 \mathrm{mmol})$, hydroxylamine hydrochloride $(5.70 \mathrm{~g}, 82 \mathrm{mmol})$ and sodium acetate $(6.7 \mathrm{~g}, 82 \mathrm{mmol})$ were stirred in $\mathrm{H}_{2} \mathrm{O}\left(250 \mathrm{~cm}^{3}\right)$ at $90{ }^{\circ} \mathrm{C}$ for $13 \mathrm{~h}$. The reaction mixture was allowed to cool to room temp., and was then extracted with $\mathrm{CH}_{2} \mathrm{Cl}_{2}\left(3 \times 200 \mathrm{~cm}^{3}\right)$. The organic layers were combined, washed with $\mathrm{H}_{2} \mathrm{O}\left(2 \times 150 \mathrm{~cm}^{3}\right)$, dried $\left(\mathrm{Na}_{2} \mathrm{SO}_{4}\right)$ and concentrated to yield the crude products as a yellow gum, separation by flash chromatography $\left(\mathrm{Et}_{2} \mathrm{O}\right.$ : pet. spirit, $\left.1: 12\right)$, gave $Z$-7d a yellow oil which was further purified by fractional distillation $(5.9 \mathrm{~g}, 49 \%)$ and $E-7 \mathbf{d}$ as a white solid which was further purified by crystallization $(5.6 \mathrm{~g}, 47 \%) . Z-7 \mathrm{~d}: \delta_{\mathrm{H}} 2.52(\mathrm{~m}, 2 \mathrm{H}$, $\left.\mathrm{OCH}_{2} \mathrm{CH}_{2}\right), 4.45\left(\mathrm{t}, 2 \mathrm{H}, \mathrm{OCH}_{2}\right), 5.12\left(\mathrm{~m}, 2 \mathrm{H}, \mathrm{CH}=\mathrm{CH}_{2}\right), 5.82$ $\left(\mathrm{m}, 1 \mathrm{H}, \mathrm{CH}=\mathrm{CH}_{2}\right), 7.40(\mathrm{~m}, 3 \mathrm{H}, \mathrm{Ar}-\mathrm{H}), 7.57(\mathrm{~m}, 2 \mathrm{H}, 2 \times$ $o$-Ar-H), $9.30($ br s, $1 \mathrm{H}, \mathrm{OH}) ; \delta_{\mathrm{C}} 32.9\left(\mathrm{OCH}_{2} \mathrm{CH}_{2}\right), 65.1$ $\left(\mathrm{OCH}_{2}\right), 117.8\left(\mathrm{CH}=\mathrm{CH}_{2}\right), 126.5(m-\mathrm{Ar}-\mathrm{C}), 128.8$ (o-Ar-C), 129.3 (p-Ar-C), 130.5 (Ar-C), $133.4\left(\mathrm{CH}=\mathrm{CH}_{2}\right), 151.7(\mathrm{C}=\mathrm{N})$, $163.7(\mathrm{C}=\mathrm{O}) . E-7 \mathrm{~d}: \delta_{\mathrm{H}} 2.41\left(\mathrm{~m}, 2 \mathrm{H}, \mathrm{OCH}_{2} \mathrm{CH}_{2}\right), 4.30(\mathrm{t}, 2 \mathrm{H}$, $\left.\mathrm{OCH}_{2}\right), 5.05\left(\mathrm{~m}, 2 \mathrm{H}, \mathrm{CH}=\mathrm{CH}_{2}\right), 5.75\left(\mathrm{~m}, 1 \mathrm{H}, \mathrm{CH}=\mathrm{CH}_{2}\right), 7.42$ (m, 3H, Ar-H), $7.5(\mathrm{~m}, 2 \mathrm{H}, 2 \times o-\mathrm{Ar}-\mathrm{H}), 10.1$ (br s, $1 \mathrm{H}, \mathrm{OH})$; $\delta_{\mathrm{C}} 32.8\left(\mathrm{OCH}_{2} \mathrm{CH}_{2}\right), 65.1\left(\mathrm{OCH}_{2}\right), 117.7\left(\mathrm{CH}=\mathrm{CH}_{2}\right), 128.0$ (m-Ar-C), 128.5 (Ar-C), 129.4 (Ar-C), 129.8 (Ar-C), 133.5 $\left(\mathrm{CH}=\mathrm{CH}_{2}\right), 149.8(\mathrm{C}=\mathrm{N}), 163.3(\mathrm{C}=\mathrm{O})$.

\section{5,6-Dihydro-3,5-dimethyl-1,4-oxazin-2-one $\mathrm{N}$-oxide 8a}

A solution of the oxime $E-7 \mathbf{a}(2.75 \mathrm{~g}, 19 \mathrm{mmol})$ in mesitylene $\left(500 \mathrm{~cm}^{3}\right)$ at $165^{\circ} \mathrm{C}$ was stirred under a nitrogen atmosphere for $28 \mathrm{~h}$ in the presence of hydroquinone $(1 \% \mathrm{w} / \mathrm{v})$. The reaction mixture was cooled to room temp., and the solvent removed under reduced pressure $\left(100{ }^{\circ} \mathrm{C}, 0.50 \mathrm{mmHg}\right)$ to give a brown gummy residue which was taken up in $\mathrm{CHCl}_{3}\left(3 \mathrm{~cm}^{3}\right)$ and allowed to stand at room temp. $(0.5 \mathrm{~h})$, the precipitated hydro- quinone was removed in vacuo, and the filtrate was concentrated under reduced pressure. Purification of the crude products by flash chromatography $\left(\mathrm{Et}_{2} \mathrm{O}:\right.$ pet. spirit, $\left.2: 1\right)$ gave unchanged oxime $(0.14 \mathrm{~g}, 5 \%)$, small amounts of two indistinguishable diastereomeric dimeric adducts 9a(i) $(0.06 \mathrm{~g}, 2 \%$, colourless cubic crystals, $\mathrm{Et}_{2} \mathrm{O}-$ hexane, $\mathrm{mp} 128-130{ }^{\circ} \mathrm{C}$ ) and 9a(ii) $\left(0.10 \mathrm{~g}, 4 \%\right.$, colourless cubic crystals, $\mathrm{Et}_{2} \mathrm{O}$-hexane, $\mathrm{mp}$ $170-172{ }^{\circ} \mathrm{C}$ ) and the dipole $8 \mathbf{a}$, a highly viscous orange oil which was further purified to a pale yellow oil by fractional distillation $(2.34 \mathrm{~g}, 85 \%) .9 \mathrm{a}(\mathrm{i}): \delta_{\mathrm{H}} 1.18\left(\mathrm{~d}, 3 \mathrm{H}, \mathrm{Me}^{7}, J 6.60\right)$, $1.61\left(\mathrm{~s}, 3 \mathrm{H}, \mathrm{Me}^{3 \mathrm{a}}\right), 2.12\left(\mathrm{~s}, 3 \mathrm{H}, \mathrm{Me}^{\prime}\right), 2.52\left(\mathrm{~m}, 2 \mathrm{H}, \mathrm{H}^{3 \mathrm{~A}}\right.$ and $\left.\mathrm{H}^{3 \mathrm{~B}}\right)$, $3.21\left(\mathrm{~m}, 1 \mathrm{H}, \mathrm{H}^{7}\right), 4.03\left(\mathrm{dd}, 1 \mathrm{H}, \mathrm{H}^{6 \mathrm{~B}}, J_{6 \mathrm{~B}, 7} 10.26, J_{6 \mathrm{~B}, 6 \mathrm{~A}} 10.99\right)$, $4.24\left(\mathrm{dd}, 1 \mathrm{H}, \mathrm{H}^{6 \mathrm{~A}}, J_{6 \mathrm{~A}, 7} 8.06, J_{6 \mathrm{~A}, 6 \mathrm{~B}} 10.99\right), 4.51$ and $4.34(2 \times \mathrm{m}$, $1 \times 2 \mathrm{H}, 1 \times 1 \mathrm{H}, \mathrm{H}^{2}$ and $\left.\mathrm{OCH}^{2}\right), 9.70($ br s, $1 \mathrm{H}, \mathrm{OH}) ; \delta_{\mathrm{C}} 10.6$ $\left(\mathrm{Me}^{7}\right), 14.4\left(\mathrm{Me}^{3 \mathrm{a}}\right), 25.5\left(\mathrm{Me}^{\prime}\right), 41.4\left(\mathrm{C}^{3}\right), 55.6\left(\mathrm{C}^{7}\right), 65.0$ $\left(\mathrm{OCH}^{2}\right), 69.1\left(\mathrm{C}^{6}\right), 70.1\left(\mathrm{C}^{3 \mathrm{a}}\right), 76.5\left(\mathrm{C}^{2}\right), 149.6(\mathrm{C}=\mathrm{N}), 163.5$ $\left(\mathrm{C}=\mathrm{O}\right.$, ester), $171.6\left(\mathrm{C}_{4}, \mathrm{C}=\mathrm{O}\right)$ (Found: $\mathrm{C}, 50.64 ; \mathrm{H}, 5.99$; N, 9.61. $\mathrm{C}_{12} \mathrm{H}_{18} \mathrm{~N}_{2} \mathrm{O}_{6}$ requires $\mathrm{C}, 50.35 ; \mathrm{H}, 6.29 ; \mathrm{N}, 9.79 \%$ ). 9a(ii): $\delta_{\mathrm{H}} 1.23\left(\mathrm{~d}, 3 \mathrm{H}, \mathrm{Me}^{7}, J 6.59\right), 1.64\left(\mathrm{~s}, 3 \mathrm{H}, \mathrm{Me}^{3 \mathrm{a}}\right), 2.12(\mathrm{~s}, 3 \mathrm{H}$, $\left.\mathrm{Me}^{\prime}\right), 2.26\left(\mathrm{dd}, 1 \mathrm{H}, \mathrm{H}^{3 \mathrm{~A}}, J_{3 \mathrm{~A}, 2} 6.60, J_{3 \mathrm{~A}, 3 \mathrm{~B}} 13.19\right), 2.88(\mathrm{dd}, 1 \mathrm{H}$, $\left.\mathrm{H}^{3 \mathrm{~B}}, J_{3 \mathrm{~B}, 2} 8.79, J_{3 \mathrm{~B}, 3 \mathrm{~A}} 13.19\right), 3.13\left(\mathrm{~m}, 1 \mathrm{H}, \mathrm{H}^{7}\right), 4.03\left(\mathrm{t}, 1 \mathrm{H}, \mathrm{H}^{6 \mathrm{~B}}\right.$, $\left.J_{6 \mathrm{~B}, 7 \mathrm{~B}}, J_{6 \mathrm{~B}, 6 \mathrm{~A}} 10.99\right), 4.24\left(\mathrm{dd}, 1 \mathrm{H}, \mathrm{H}^{6 \mathrm{~A}}, J_{6 \mathrm{~A}, 7} 8.80, J_{6 \mathrm{~A}, 6 \mathrm{~B}} 10.99\right)$, $4.40\left(\mathrm{~m}, 3 \mathrm{H}, \mathrm{H}^{2}\right.$ and $\left.\mathrm{OCH}^{2}\right), 9.98($ br s, $1 \mathrm{H}, \mathrm{OH}) ; \delta_{\mathrm{C}} 10.70$ $\left(\mathrm{Me}^{7}\right), 14.5\left(\mathrm{Me}^{3 \mathrm{a}}\right), 29.8\left(\mathrm{Me}^{\prime}\right), 43.3\left(\mathrm{C}^{3}\right), 52.6\left(\mathrm{C}^{7}\right), 65.3$ $\left(\mathrm{OCH}^{2}\right), 69.6\left(\mathrm{C}^{6}\right), 69.7\left(\mathrm{C}^{3 \mathrm{a}}\right), 73.8\left(\mathrm{C}^{2}\right), 149.1(\mathrm{C}=\mathrm{N}), 163.5$ $(\mathrm{C}=\mathrm{O}), 172.4\left(\mathrm{C}^{4}, \mathrm{C}=\mathrm{O}\right)$ (Found: $\mathrm{C}, 50.40 ; \mathrm{H}, 6.40 ; \mathrm{N}, 9.52$. $\mathrm{C}_{12} \mathrm{H}_{18} \mathrm{~N}_{2} \mathrm{O}_{6}$ requires $\left.\mathrm{C}, 50.35 ; \mathrm{H}, 6.29 ; \mathrm{N}, 9.79 \%\right) .8 \mathrm{a}: \delta_{\mathrm{H}} 1.58$ $\left(\mathrm{d}, 3 \mathrm{H}, \mathrm{Me}^{5}, J\right.$ 6.78), $2.23\left(\mathrm{~s}, 3 \mathrm{H}, \mathrm{Me}^{3}\right), 4.19\left(\mathrm{~m}, 1 \mathrm{H}, \mathrm{H}^{5}\right), 4.30$ $\left(\mathrm{dd}, 1 \mathrm{H}, \mathrm{H}^{6 \mathrm{~B}}, J_{6 \mathrm{~B}, 5} 5.68, J_{6 \mathrm{~B}, 6 \mathrm{~A}} 12.10\right), 4.62\left(\mathrm{dd}, 1 \mathrm{H}, \mathrm{H}^{6 \mathrm{~A}}, J_{6 \mathrm{~A}, 5}\right.$ 3.66, $\left.J_{6 \mathrm{~A}, 6 \mathrm{~B}} 12.27\right) ; \delta_{\mathrm{C}} 11.8\left(\mathrm{Me}^{5}\right), 14.4\left(\mathrm{Me}^{3}\right), 62.9\left(\mathrm{C}^{5}\right), 67.1$ $\left(\mathrm{C}^{6}\right), 135.1\left(\mathrm{C}^{3}, \mathrm{C}=\mathrm{N}\right), 159.2\left(\mathrm{C}^{2}, \mathrm{C}=\mathrm{O}\right)$.

\section{$\left(3 \mathrm{a} S^{*}, 6 \mathrm{a} R^{*}\right)$-Tetrahydro-6a-methylfuro[3,4-c]isoxazol-6-one 10a}

A solution of the oxime $E-7 \mathbf{a}(3.21 \mathrm{~g}, 22.50 \mathrm{mmol})$ in $\mathrm{H}_{2} \mathrm{O}(90$ $\left.\mathrm{cm}^{3}\right)$ at $100{ }^{\circ} \mathrm{C}$ was stirred for $48 \mathrm{~h}$. The reaction mixture was cooled to room temp., and was extracted with $\mathrm{CH}_{2} \mathrm{Cl}_{2}(4 \times 100$ $\left.\mathrm{cm}^{3}\right)$. The organic layers were combined, dried $\left(\mathrm{Na}_{2} \mathrm{SO}_{4}\right)$ and concentrated to give a yellow solid $(0.65 \mathrm{~g}, 20 \%)$, which was purified by flash chromatography $\left(\mathrm{Et}_{2} \mathrm{O}\right)$ to give unchanged oxime $E-7$ a $(0.50 \mathrm{~g}, 16 \%)$ and the adduct 10a $(0.13 \mathrm{~g}, 4 \%)$, which crystallized to colourless cubic crystals. Careful evaporation $\left(70{ }^{\circ} \mathrm{C}, 15 \mathrm{mmHg}\right)$ of the aqueous layer gave a brown gummy residue $(0.19 \mathrm{~g}, 6 \%)$ which was decomposed organic material. $\delta_{\mathrm{H}} 1.58(\mathrm{~s}, 3 \mathrm{H}, \mathrm{Me}), 3.08\left(\mathrm{~m}, 1 \mathrm{H}, \mathrm{H}^{3 \mathrm{a}}\right), 3.99(\mathrm{dd}, 1 \mathrm{H}$, $\left.\mathrm{H}^{4 \mathrm{~B}}, J_{4 \mathrm{~B}, 4 \mathrm{~A}} 6.59, J_{4 \mathrm{~B}, 3 \mathrm{a}} 8.80\right), 4.15\left(\mathrm{dd}, 1 \mathrm{H}, \mathrm{H}^{4 \mathrm{~A}}, J_{4 \mathrm{~A}, 4 \mathrm{~B}} 6.60, J_{4 \mathrm{~A}, 3 \mathrm{a}}\right.$ 2.94), $4.22\left(\mathrm{dd}, 1 \mathrm{H}, \mathrm{H}^{3 \mathrm{~B}}, J_{3 \mathrm{~B}, 3 \mathrm{~A}} 9.53, J_{3 \mathrm{~B}, 3 \mathrm{a}} 2.93\right), 4.54(\mathrm{dd}, 1 \mathrm{H}$, $\left.\mathrm{H}^{3 \mathrm{~A}}, J_{3 \mathrm{~A}, 3 \mathrm{~B}} 9.53, J_{3 \mathrm{~A}, 3 \mathrm{a}} 8.06\right), 5.45(\mathrm{br} \mathrm{s}, 1 \mathrm{H}, \mathrm{NH}) ; \delta_{\mathrm{C}} 17.0(\mathrm{Me})$, $47.8\left(\mathrm{C}^{3 \mathrm{a}}\right), 67.6\left(\mathrm{C}^{4}\right), 69.4\left(\mathrm{C}^{3}\right), 77.6\left(\mathrm{C}^{6 \mathrm{a}}\right), 176.1(\mathrm{C}=\mathrm{O})$. NOEDS experimental results indicate cis stereochemistry at the ring junction, irradiation of $\mathrm{H}^{3 \mathrm{a}}$ caused a $2.9 \%$ enhancement on the methyl group.

\section{5,6-Dihydro-5-methyl-3-phenyl-1,4-oxazin-2-one $\mathrm{N}$-oxide $8 \mathrm{~b}$}

A solution of the oxime $E-7 \mathbf{b}(0.90 \mathrm{~g}, 4.39 \mathrm{mmol})$ in xylene ( 250 $\mathrm{cm}^{3}$ ) was stirred at $138{ }^{\circ} \mathrm{C}$ under a nitrogen atmosphere for $30 \mathrm{~h}$ in the presence of hydroquinone $(1.0 \% \mathrm{w} / \mathrm{v})$. The reaction mixture was cooled to room temp., and the solvent was removed under reduced pressure $\left(100^{\circ} \mathrm{C}, 0.25 \mathrm{mmHg}\right)$. The solid residue was taken up in $\mathrm{CHCl}_{3}\left(3 \mathrm{~cm}^{3}\right)$ and allowed to stand at room temp. $(0.5 \mathrm{~h})$, the precipitated hydroquinone was removed by filtration in vacuo and the filtrate was concentrated under reduced pressure. Purification of the crude mixture by flash chromatography $\left(\mathrm{Et}_{2} \mathrm{O}\right.$ : pet. spirit, $\left.2: 1\right)$ gave unchanged starting oxime $E-7 \mathbf{b},(0.020 \mathrm{~g}, 2 \%)$, a dimeric adduct $9 \mathbf{b}(0.06 \mathrm{~g}, 7 \%$, colourless cubic crystals, mp $155-158{ }^{\circ} \mathrm{C}$, benzene-pet. spirit) and the dipole $8 \mathbf{b}(0.77 \mathrm{~g}, 85 \%) .9 \mathrm{~b}: \delta_{\mathrm{H}} 1.19(\mathrm{~d}, 3 \mathrm{H}, \mathrm{Me}, J 6.59)$, 2.52 and $2.48\left(2 \times \mathrm{dd}, 2 \times 1 \mathrm{H}, \mathrm{H}^{3 \mathrm{~A}}\right.$ and $\left.\mathrm{H}^{3 \mathrm{~B}}\right), 3.25\left(\mathrm{~m}, 1 \mathrm{H}, \mathrm{H}^{7}\right)$, $4.35\left(\mathrm{~m}, 2 \mathrm{H}, \mathrm{H}^{1^{\prime} \mathrm{A}}\right.$ and $\left.\mathrm{H}^{1^{\prime} \mathrm{B}}\right), 4.80$ and $4.73\left(2 \times \mathrm{dd}, 2 \times 1 \mathrm{H}, \mathrm{H}^{6 \mathrm{~A}}\right.$ and $\left.\mathrm{H}^{6 \mathrm{~B}}\right), 4.95\left(\mathrm{~m}, 1 \mathrm{H}, \mathrm{H}^{2}\right), 8.73-7.19(2 \times \mathrm{m}, 10 \mathrm{H}, \mathrm{Ar}-\mathrm{H})$, 
10.15 (br s, $1 \mathrm{H}, \mathrm{OH}) ; \delta_{\mathrm{C}} 15.9(\mathrm{Me}), 45.8\left(\mathrm{C}^{3}\right), 56.6\left(\mathrm{C}^{7}\right), 65.5$ $\left(\mathrm{OCH}^{2}\right), 68.6\left(\mathrm{C}^{6}\right), 74.3\left(\mathrm{C}^{3 \mathrm{a}}\right), 74.6\left(\mathrm{C}^{2}\right), 140.0-126.2(8 \times$ Ar-C), $149.5(\mathrm{C}=\mathrm{N}), 162.9\left(\mathrm{C}_{4}, \mathrm{C}=\mathrm{O}\right), 171.1(\mathrm{C}=\mathrm{O}$, ester $)$ (Found: $\mathrm{C}, 64.56 ; \mathrm{H}, 5.39 ; \mathrm{N}, 6.49 . \mathrm{C}_{22} \mathrm{H}_{22} \mathrm{~N}_{2} \mathrm{O}_{6}$ requires $\mathrm{C}$, $64.39 ; \mathrm{H}, 5.35 ; \mathrm{N}, 6.78 \%) .8 \mathbf{b}: \delta_{\mathrm{H}} 1.66\left(\mathrm{~d}, 3 \mathrm{H}, \mathrm{Me}^{5}\right), 4.33(\mathrm{~m}, 2 \mathrm{H}$, $\mathrm{H}^{6 \mathrm{~B}}$ and $\left.\mathrm{H}^{5}\right), 4.70\left(\mathrm{dd}, 1 \mathrm{H}, \mathrm{H}^{6 \mathrm{~A}}, J_{6 \mathrm{~A}, 5} 3.30, J_{6 \mathrm{~A}, 6 \mathrm{~B}} 11.72\right), 7.44(\mathrm{~m}$, $3 \mathrm{H}, m$ - and $p-\mathrm{Ar}-\mathrm{H}), 7.70(\mathrm{~m}, 2 \mathrm{H}, 2 \times o-\mathrm{Ar}-\mathrm{H}) ; \delta_{\mathrm{C}} 14.7(\mathrm{Me})$, $64.8\left(\mathrm{C}^{5}\right), 66.9\left(\mathrm{C}^{6}\right), 134.5-127.5(4 \times \mathrm{Ar}-\mathrm{C}), 136.2\left(\mathrm{C}^{3}, \mathrm{C}=\mathrm{N}\right)$, $158.9\left(\mathrm{C}^{2}, \mathrm{C}=\mathrm{O}\right)$.

$\left(3 \mathrm{a} S^{*}, 6 \mathrm{a} S^{*}\right)$-Tetrahydro-6a-phenylfuro[3,4-c]isoxazol-6-one $10 \mathrm{~b}$

Method A. A solution of the oxime $Z-7 \mathbf{b}(0.76 \mathrm{~g}, 3.7 \mathrm{mmol})$ in xylene $\left(225 \mathrm{~cm}^{3}\right)$ was stirred at $138^{\circ} \mathrm{C}$ under a nitrogen atmosphere for $36 \mathrm{~h}$ in the presence of hydroquinone $(1.0 \% \mathrm{w} / \mathrm{v})$. The reaction mixture was cooled to room temp. and the solvent removed under reduced pressure $\left(100{ }^{\circ} \mathrm{C}, 0.5 \mathrm{mmHg}\right)$. The gummy residue was taken up in $\mathrm{CHCl}_{3}\left(2.5 \mathrm{~cm}^{3}\right)$ and allowed to stand at room temp. $(0.5 \mathrm{~h})$, the precipitated hydroquinone removed by filtration in vacuo, and the filtrate was concentrated. Purification of the crude products by flash chromatography $\left(\mathrm{Et}_{2} \mathrm{O}:\right.$ pet. spirit, $\left.1.0: 2.5\right)$ gave unchanged starting oxime $Z-7 \mathbf{b}(0.22 \mathrm{~g}, 29 \%)$, and the adduct $\mathbf{1 0 b}$, a viscous yellow oil which solidified upon trituration (pet. spirit) $(0.5 \mathrm{~g}, 66 \%)$. 10b: $\delta_{\mathrm{H}} 3.57\left(\mathrm{~m}, 1 \mathrm{H}, \mathrm{H}^{3 \mathrm{a}}\right), 4.21\left(\mathrm{~m}, 2 \mathrm{H}, \mathrm{H}^{4 \mathrm{~A}}\right.$ and $\left.\mathrm{H}^{4 \mathrm{~B}}\right), 4.40(\mathrm{dd}$, $\left.1 \mathrm{H}, \mathrm{H}^{3 \mathrm{~A}}, J_{3 \mathrm{~A}, 3 \mathrm{~B}} 9.89, J_{3 \mathrm{~A}, 3 \mathrm{a}} 2.02\right), 4.63\left(\mathrm{dd}, 1 \mathrm{H}, \mathrm{H}^{3 \mathrm{~B}}, J_{3 \mathrm{~B}, 3 \mathrm{~A}} 9.89\right.$ $\left.\mathrm{H}, J_{3 \mathrm{~B}, 3 \mathrm{a}} 7.14\right), 5.92$ (br s, $\left.1 \mathrm{H}, \mathrm{NH}\right), 7.55-7.29(2 \times \mathrm{m}, 5 \mathrm{H}$, $\mathrm{Ar}-\mathrm{H}) ; \delta_{\mathrm{C}} 49.4\left(\mathrm{C}^{3 a}\right), 70.8\left(\mathrm{C}^{4}\right), 75.2\left(\mathrm{C}^{3}\right), 78.6\left(\mathrm{C}^{6 a}\right), 133.5-126.5$ $(4 \times$ Ar-C), $176.6(\mathrm{C}=\mathrm{O})$; NOEDS indicated cis fusion at the ring junction, irradiation of $\mathrm{H}^{3 a}$ caused a $4.3 \%$ enhancement on the $o$ - $\mathrm{ArH}$

Method B. Aqueous preparation of 10b. The oxime $E-7 \mathbf{b}(1.50$ g, $7.3 \mathrm{mmol})$ was stirred in $\mathrm{H}_{2} \mathrm{O}\left(120 \mathrm{~cm}^{3}\right)$ at $100{ }^{\circ} \mathrm{C}$ for $18 \mathrm{~h}$. The reaction mixture was allowed to cool to room temp. and the aqueous solution was extracted with $\mathrm{CH}_{2} \mathrm{Cl}_{2}\left(4 \times 100 \mathrm{~cm}^{3}\right)$. The organic layers were combined, dried $\left(\mathrm{Na}_{2} \mathrm{SO}_{4}\right)$ and concentrated to yield the crude products as a yellow gum $(1.46 \mathrm{~g}, 97 \%)$. This residue was taken up in benzene-pet. spirit and allowed to stand at $0{ }^{\circ} \mathrm{C}$ overnight, adduct $\mathbf{1 0 b}$ crystallized as colourless rods which were collected by filtration $(0.85 \mathrm{~g}, 57 \%)$. The filtrate was concentrated and further purified by flash chromatography $\left(\mathrm{Et}_{2} \mathrm{O}\right.$ : pet. spirit, 1.0:1.5) giving three fractions. Fraction one, a viscous yellow oil, contained unchanged starting oxime $E-7 \mathbf{b}$ $(0.15 \mathrm{~g}, 10 \%)$. Fraction two gave oxime $Z-7 \mathbf{b}(0.22 \mathrm{~g}, 15 \%)$ as a yellow gum. Fraction three (a diethyl ether strip) gave adduct 10b, which upon crystallization $\left(\mathrm{Et}_{2} \mathrm{O}\right.$-pet. spirit) gave colourless rods $(0.16 \mathrm{~g}, 11 \%, 67 \%$ total $)$.

\section{Thermal reaction of oxime $E-7 \mathrm{c}$. Preparation of $8 \mathrm{c}$ and $10 \mathrm{c}$}

A solution of the anti-oxime $E-7 \mathrm{c}(0.91 \mathrm{~g}, 3.50 \mathrm{mmol})$ in xylene $\left(250 \mathrm{~cm}^{3}\right)$ was heated at $140{ }^{\circ} \mathrm{C}$ under a nitrogen atmosphere for $35 \mathrm{~h}$ in the presence of hydroquinone $(1.0 \% \mathrm{w} / \mathrm{v})$. The reaction mixture was cooled to room temp., and the solvent removed under reduced pressure $\left(100{ }^{\circ} \mathrm{C}, 0.5 \mathrm{mmHg}\right)$. The yellow gummy residue was taken up in $\mathrm{CHCl}_{3}\left(2 \mathrm{~cm}^{3}\right)$ and allowed to stand at room temp. for $0.5 \mathrm{~h}$, the precipitated hydroquinone was filtered off in vacuo and the filtrate was concentrated. The crude products were isolated by flash chromatography $\left(\mathrm{Et}_{2} \mathrm{O}\right.$ :pet. spirit, $\left.1: 4\right)$ to give the syn-oxime $(Z-7 \mathrm{c}, 0.30 \mathrm{~g}$, $33 \%)$, the unchanged $E$-oxime $(E-7 \mathbf{c}, 0.20 \mathrm{~g}, 22 \%)$, the cycloadduct 10c $(0.064 \mathrm{~g}, 7 \%)$, a yellow gum which solidified upon standing to give colourless needles, $\mathrm{mp} 136-137^{\circ} \mathrm{C}$ (benzenepet. spirit) and the dipole $8 \mathbf{c}$ a yellow gum which was crystallized from benzene-pet. spirit to give colourless cubic crystals $(0.30 \mathrm{~g}, 33 \%), \mathrm{mp} 93-95^{\circ} \mathrm{C}$. (3aR*,4S*,6aS*)-Tetrahydro-4tert-butyl-6a-phenylfuro[3,4-c]isoxazol-6-one 10c: $\delta_{\mathrm{H}} 0.97(\mathrm{~s}, 9 \mathrm{H}$, $3 \times \mathrm{Me}), 3.25\left(\mathrm{~m}, 1 \mathrm{H}, \mathrm{H}^{3 \mathrm{a}}\right), 3.82\left(\mathrm{~d}, 1 \mathrm{H}, \mathrm{H}^{4}, J_{4,3 \mathrm{a}} 6.59\right), 4.32(\mathrm{dd}$, $\left.1 \mathrm{H}, \mathrm{H}^{3 \mathrm{~A}}, J_{3 \mathrm{~A}, 3 \mathrm{a}} 9.52, J_{3 \mathrm{~A}, 3 \mathrm{~B}} 3.86\right), 4.50\left(\mathrm{dd}, 1 \mathrm{H}, \mathrm{H}^{3 \mathrm{~B}}, J_{3 \mathrm{~B}, 3 \mathrm{~A}} 9.52\right.$, $\left.J_{3 \mathrm{~B}, 3 \mathrm{a}} 5.86\right), 6.11($ br s, $1 \mathrm{H}, \mathrm{NH}), 7.47-7.23(2 \times \mathrm{m}, 5 \mathrm{H}, \mathrm{Ar}-\mathrm{H})$; $\delta_{\mathrm{C}} 26.0\left(\mathrm{CMe}_{3}\right), 34.7\left(\mathrm{CMe}_{3}\right), 53.6\left(\mathrm{C}^{6 \mathrm{a}}\right), 69.4\left(\mathrm{C}^{3}\right), 96.6\left(\mathrm{C}^{4}\right)$, 134.7-126.4 (4 × Ar-C), $160.4\left(\mathrm{C}_{6}, \mathrm{C}=\mathrm{O}\right)$. NOEDS experi- mental results indicate cis stereochemistry at the ring junction, irradiation of $\mathrm{H}^{3 \mathrm{a}}$ caused a $3.7 \%$ enhancement on the $o-\mathrm{ArH}$; $\mathrm{H}^{3 \mathrm{a}}$ and $\mathrm{H}^{4}$ are deduced to have a trans relationship as they show no mutual enhancement on irradiation. $(5 \mathrm{R} *, 6 \mathrm{~S} *)$-6-tertButyl-5,6-dihydro-5-methyl-3-phenyl-1,4-oxazin-2-one $\mathrm{N}$-oxide 8c: $\delta_{\mathrm{H}} 1.00(\mathrm{~s}, 9 \mathrm{H}, 3 \times \mathrm{Me}), 1.70\left(\mathrm{~d}, 3 \mathrm{H}, \mathrm{Me}^{5}, J 7.33\right), 3.99(\mathrm{~s}$, $\left.1 \mathrm{H}, \mathrm{H}^{6}\right), 4.28\left(\mathrm{q}, 1 \mathrm{H}, \mathrm{H}^{5}, J 7.33\right), 7.34(\mathrm{~m}, 3 \mathrm{H}, m-$ and $p-\mathrm{Ar}-\mathrm{H})$, $7.59(\mathrm{~m}, 2 \mathrm{H}, o-\mathrm{Ar}-\mathrm{H}) ; \delta_{\mathrm{C}} 20.5\left(\mathrm{Me}^{5}\right), 25.8\left(\mathrm{CMe}_{3}\right), 35.9\left(\mathrm{CMe}_{3}\right)$, $64.9\left(\mathrm{C}^{5}\right), 85.0\left(\mathrm{C}^{6}\right), 130.1-128.0(4 \times \mathrm{Ar}-\mathrm{C}), 158.1(\mathrm{C}=\mathrm{N})$, $162.4\left(\mathrm{C}^{2}, \mathrm{C}=\mathrm{O}\right)$. NOEDS experimental results indicate a trans relationship between the methyl group on $\mathrm{C}^{5}$ and the $\mathrm{Bu}^{t}$ group on $\mathrm{C}^{6}$; irradiation of $\mathrm{H}^{5}$ causes a $9.3 \%$ enhancement on the $\mathrm{Bu}^{t}$ group and a $3.8 \%$ enhancement on $\mathrm{Me}^{5}$; irradiation of $\mathrm{H}^{6}$ causes a $3.3 \%$ enhancement on $\mathrm{H}^{5}$, a $3.5 \%$ enhancement on $\mathrm{Me}^{5}$ and a $5.4 \%$ enhancement on the $\mathrm{Bu}^{t}$ group.

\section{6,7-Dihydro-5-methyl-3-phenyl-5H-1,4-oxazepin-2-one $\mathrm{N}$-oxide} 8d

A solution of the oxime $E-7 \mathbf{d}(3.00 \mathrm{~g}, 13.70 \mathrm{mmol})$ in xylene $\left(900 \mathrm{~cm}^{3}\right)$ was stirred at $140{ }^{\circ} \mathrm{C}$ under a nitrogen atmosphere for $24 \mathrm{~h}$ in the presence of hydroquinone $(1.0 \% \mathrm{w} / \mathrm{v})$. The reaction mixture was cooled to room temp., and the solvent removed under reduced pressure $\left(100{ }^{\circ} \mathrm{C}, 0.2 \mathrm{mmHg}\right)$. The yellow gummy residue was taken up in $\mathrm{CHCl}_{3}\left(5 \mathrm{~cm}^{3}\right)$ and allowed to stand at room temp. for $0.5 \mathrm{~h}$, the precipitated hydroquinone was filtered off in vacuo and the filtrate concentrated. Purification of the crude products by flash chromatography $\left(\mathrm{Et}_{2} \mathrm{O}\right.$ : pet. spirit, $\left.1: 4\right)$ gave oxime $Z$-7d as a colourless oil $(0.90$ g, 30\%), unchanged starting oxime $E-7$ d $(0.85 \mathrm{~g}, 28 \%)$, two indistinguishable stereoisomeric dimeric adducts $9 d(i)(0.06 \mathrm{~g}$, $2.0 \%$, pale yellow crystals, $\mathrm{mp} 130-131^{\circ} \mathrm{C}$ from benzene-pet. spirit) and 9d(ii) (0.035 g, 1.2\%, pale yellow crystals, mp 114 $116^{\circ} \mathrm{C}$ from benzene-pet. spirit) and the nitrone $8 \mathbf{d}$ as a yellow gum which was triturated and crystallized from benzene-pet. spirit to give pale yellow cubic crystals $(0.95 \mathrm{~g}, 32 \%)$. 9d(i): $\delta_{\mathrm{H}} 1.25(\mathrm{~d}, 3 \mathrm{H}, \mathrm{Me}, J 5.87), 2.16-1.61\left(\mathrm{~m}, 4 \mathrm{H}, \mathrm{H}^{7 \mathrm{~A}}, \mathrm{H}^{7 \mathrm{~B}}\right.$ and $\left.\mathrm{OCH}_{2} \mathrm{CH}^{2^{\prime}}\right), 2.20\left(\mathrm{dd}, 1 \mathrm{H}, \mathrm{H}^{3 \mathrm{~B}}, J_{3 \mathrm{~B}, 3 \mathrm{~A}} 12.82, J_{3 \mathrm{~B}, 2} 8.80\right), 3.27$ $\left(\mathrm{m}, 1 \mathrm{H}, \mathrm{H}^{8}\right), 3.72\left(\mathrm{dd}, 1 \mathrm{H}, \mathrm{H}^{3 \mathrm{~A}}, J_{3 \mathrm{~A}, 3 \mathrm{~B}} 12.82, J_{3 \mathrm{~A}, 2} 6.96\right), 3.86(\mathrm{dd}$, $\left.1 \mathrm{H}, \mathrm{H}^{6 \mathrm{~B}}, J_{6 \mathrm{~B}, 6 \mathrm{~A}} 2.09, J_{6 \mathrm{~b}, 7 \mathrm{~A} / 7 \mathrm{~B}} 3.23\right), 4.43-4.24\left(3 \times \mathrm{m}, 4 \mathrm{H}, \mathrm{H}^{2}\right.$, $\mathrm{H}^{6 \mathrm{~A}}$ and $\left.\mathrm{OCH}_{2} \mathrm{CH}^{2}\right), 7.63-7.25(3 \times \mathrm{m}, 10 \times \mathrm{Ar}-\mathrm{H}), 9.63(\mathrm{br} \mathrm{s}$, $1 \mathrm{H}, \mathrm{OH}) ; \delta_{\mathrm{C}} 18.6(\mathrm{Me}), 36.5$ and $32.1\left(\mathrm{C}^{7}\right.$ and $\left.\mathrm{OCH}_{2} \mathrm{CH}^{2^{\prime}}\right), 50.4$ $\left(\mathrm{C}^{3}\right), 53.6\left(\mathrm{C}^{8}\right), 62.5\left(\mathrm{OCH}_{2} \mathrm{CH}^{2^{\prime}}\right), 64.0\left(\mathrm{C}^{6}\right), 73.7\left(\mathrm{C}^{3 \mathrm{a}}\right), 82.8$ $\left(\mathrm{C}^{2}\right), 140.9-125.2(10 \times \mathrm{Ar}-\mathrm{C}), 149.4(\mathrm{C}=\mathrm{N}), 163.6\left(\mathrm{C}_{4}, \mathrm{C}=\mathrm{O}\right)$, $171.7(\mathrm{C}=\mathrm{O}$, ester) (Found: $\mathrm{C}, 65.99 ; \mathrm{H}, 5.99 ; \mathrm{N}, 6.21$. $\mathrm{C}_{24} \mathrm{H}_{26} \mathrm{~N}_{2} \mathrm{O}_{6}$ requires C, 65.75; H, 5.94; N, 6.39\%). 9d(ii): $\delta_{\mathrm{H}} 1.20$ $\left(\mathrm{d}, 3 \mathrm{H}, \mathrm{Me}, J\right.$ 6.59), 2.14-1.67 $\left(3 \times \mathrm{m}, 4 \mathrm{H}, \mathrm{H}^{7 \mathrm{~A}}, \mathrm{H}^{7 \mathrm{~B}}\right.$ and $\left.\mathrm{OCH}_{2} \mathrm{CH}^{2^{\prime}}\right), 2.16\left(\mathrm{dd}, 1 \mathrm{H}, \mathrm{H}^{3 \mathrm{~B}}, J_{3 \mathrm{~B}, 3 \mathrm{~A}} 13.19, J_{3 \mathrm{~B}, 2} 8.06\right), 3.20$ $\left(\mathrm{m}, 1 \mathrm{H}, \mathrm{H}^{8}\right), 3.64\left(\mathrm{dd}, 1 \mathrm{H}, \mathrm{H}^{3 \mathrm{~A}}, J_{3 \mathrm{~A}, 2} 7.33, J_{3 \mathrm{~A}, 3 \mathrm{~B}} 13.19\right), 3.86(\mathrm{dd}$, $\left.1 \mathrm{H}, \mathrm{H}^{6 \mathrm{~B}}, J_{6 \mathrm{~B}, 6 \mathrm{~A}} 12.46, J_{6 \mathrm{~B}, 7 \mathrm{~A} / 7 \mathrm{~B}} 6.60\right), 4.14\left(\mathrm{~m}, 1 \mathrm{H}, \mathrm{H}^{2}\right), 4.28(\mathrm{~m}$, $\left.3 \mathrm{H}, \mathrm{H}^{6 \mathrm{~A}}, \mathrm{OCH}_{2} \mathrm{CH}^{2^{\prime}}, J_{6 \mathrm{~A}, 6 \mathrm{~B}} 12.46, J_{6 \mathrm{~A}, 7 \mathrm{~A} / 7 \mathrm{~B}} 8.80\right), 7.61-7.25$ $\left(3 \times \mathrm{m}, 10 \times \mathrm{Ar}-\mathrm{H}\right.$ and $\left.\mathrm{Ar}^{\prime}-\mathrm{H}\right), 9.62(\mathrm{br} \mathrm{s}, 1 \mathrm{H}, \mathrm{OH}) ; \delta_{\mathrm{C}} 19.0$ $(\mathrm{Me}), 36.9$ and $32.5\left(\mathrm{C}^{7}\right.$ and $\left.\mathrm{OCH}_{2} \mathrm{CH}^{2}\right), 53.8\left(\mathrm{C}^{8}\right), 50.4\left(\mathrm{C}^{3}\right)$, $63.1\left(\mathrm{OCH}_{2} \mathrm{CH}^{2^{\prime}}\right), 64.2\left(\mathrm{C}^{6}\right), 74.1\left(\mathrm{C}^{3 \mathrm{a}}\right), 83.1\left(\mathrm{C}^{2}\right), 141.2-125.6$ $(8 \times \mathrm{Ar}-\mathrm{C}), 149.7(\mathrm{C}=\mathrm{N}), 163.2\left(\mathrm{C}^{4}, \mathrm{C}=\mathrm{O}\right), 171.6(\mathrm{C}=\mathrm{O}$, ester $)$ (Found: C, 65.76; H, 5.96; N, 6.10. $\mathrm{C}_{24} \mathrm{H}_{26} \mathrm{~N}_{2} \mathrm{O}_{6}$ requires $\mathrm{C}$, 65.75; H, 5.94; N, 6.39\%). 8d: $\delta_{\mathrm{H}} 1.57$ (d, 3H, Me, J 6.45), 2.11 $\left(\mathrm{m}, 1 \mathrm{H}, \mathrm{H}^{6 \mathrm{~A}}\right), 2.42\left(\mathrm{~m}, 1 \mathrm{H}, \mathrm{H}^{6 \mathrm{~B}}\right), 4.57-4.30\left(2 \times \mathrm{m}, 3 \mathrm{H}, \mathrm{H}^{5}, \mathrm{H}^{7 \mathrm{~A}}\right.$ and $\left.\mathrm{H}^{7 \mathrm{~B}}\right), 7.42(\mathrm{~m}, 2 \mathrm{H}, m-$ and $p-\mathrm{Ar}-\mathrm{H}), 8.07(\mathrm{~m}, 2 \mathrm{H}, o-\mathrm{Ar}-\mathrm{H})$; $\delta_{\mathrm{C}} 15.6(\mathrm{Me}), 34.6\left(\mathrm{C}^{7}\right), 64.6\left(\mathrm{C}^{8}\right), 66.1\left(\mathrm{C}^{6}\right), 136.2-128.4$ $\left(4 \times \mathrm{Ar}-\mathrm{C}, \mathrm{C}^{3}\right.$ and $\left.\mathrm{C}=\mathrm{N}\right), 165.8\left(\mathrm{C}^{2}\right.$ and $\left.\mathrm{C}=\mathrm{O}\right)$.

\section{2-(Prop-2-enyloxy)acetophenone 16a}

2-Hydroxyacetophenone (14.96 g, $0.11 \mathrm{~mol})$, allyl bromide $(19.96 \mathrm{~g}, 0.165 \mathrm{~mol})$ and potassium carbonate $(22.8 \mathrm{~g}, 0.165$ mol) were stirred using mechanical agitation in dry acetone $\left(250 \mathrm{~cm}^{3}\right)$ under reflux for $85 \mathrm{~h}$. The reaction mixture was allowed to cool to room temp., and the solvent was removed under reduced pressure. To the viscous yellow residue was added $\mathrm{H}_{2} \mathrm{O}\left(200 \mathrm{~cm}^{3}\right)$ and this aqueous solution was extracted with $\mathrm{Et}_{2} \mathrm{O}\left(4 \times 100 \mathrm{~cm}^{3}\right)$. The combined organic layers were 
collected, dried $\left(\mathrm{MgSO}_{4}\right)$ and concentrated to yield the crude product as a yellow oil. Following fractional distillation 16a $(15.1 \mathrm{~g}, 78 \%)$ was obtained as a colourless oil which solidified upon standing giving colourless plates. $\delta_{\mathrm{H}} 2.62(\mathrm{~s}, 3 \mathrm{H}, \mathrm{Me}), 4.62$ $\left(\mathrm{d}, 2 \mathrm{H}, \mathrm{OCH}_{2}\right), 5.35\left(\mathrm{~m}, 2 \mathrm{H}, \mathrm{CH}=\mathrm{CH}_{2}\right), 6.06\left(\mathrm{~m}, 1 \mathrm{H}, \mathrm{CH}=\mathrm{CH}_{2}\right)$, $6.95(\mathrm{~m}, 2 \mathrm{H}, \mathrm{Ar}-\mathrm{H}), 7.39$ (m, 1H, Ar-H), $7.75(\mathrm{~m}, 1 \mathrm{H}, \mathrm{Ar}-\mathrm{H}) ; \delta_{\mathrm{C}}$ $31.9(\mathrm{Me}), 69.4\left(\mathrm{OCH}_{2}\right), 112.9(\mathrm{Ar}-\mathrm{C}), 118.2\left(\mathrm{CH}=\mathrm{CH}_{2}\right), 120.8$ (Ar-C), 128.8 (Ar-C), 130.4 (Ar-C), 132.7 (Ar-C), 133.5 $\left(\mathrm{CH}=\mathrm{CH}_{2}\right), 158.0(\mathrm{Ar}-\mathrm{C}), 199.9(\mathrm{C}=\mathrm{O})$.

\section{2-(Prop-2-enyloxy)benzophenone 16b}

2-Hydroxybenzophenone (3.96 g, $20 \mathrm{mmol}$ ), allyl bromide (3.6 $\mathrm{g}, 30 \mathrm{mmol})$ and potassium carbonate $(4.15 \mathrm{~g}, 0.3 \mathrm{mmol})$ were stirred using mechanical agitation in acetone $\left(150 \mathrm{~cm}^{3}\right)$ under reflux for $40 \mathrm{~h}$. The reaction mixture was allowed to cool to room temp., and the reaction solvent was evaporated under reduced pressure. To the yellow oily residue was added $\mathrm{H}_{2} \mathrm{O}$ $\left(100 \mathrm{~cm}^{3}\right)$ and the resulting aqueous solution was extracted with $\mathrm{Et}_{2} \mathrm{O}\left(4 \times 75 \mathrm{~cm}^{3}\right)$. The organic layers were combined, dried $\left(\mathrm{MgSO}_{4}\right)$ and concentrated to furnish the crude product. Following fractional distillation $\mathbf{1 6 b}(4.0 \mathrm{~g}, 90 \%)$ was obtained as a colourless oil. $\delta_{\mathrm{H}} 4.46\left(\mathrm{~m}, 2 \mathrm{H}, \mathrm{OCH}_{2}\right), 5.05\left(\mathrm{~m}, 2 \mathrm{H}, \mathrm{CH}=\mathrm{CH}_{2}\right)$, $5.72\left(\mathrm{~m}, 1 \mathrm{H}, \mathrm{CH}=\mathrm{CH}_{2}\right), 7.0(\mathrm{~m}, 2 \mathrm{H}, \mathrm{Ar}-\mathrm{H}), 7.49(\mathrm{~m}, 5 \mathrm{H}, \mathrm{Ar}-\mathrm{H})$, $7.84(\mathrm{~m}, 2 \mathrm{H}, \mathrm{Ar}-\mathrm{H}) ; \delta_{\mathrm{C}} 68.9\left(\mathrm{OCH}_{2}\right), 112.7$ (Ar-C), 116.9 $\left(\mathrm{CH}=\mathrm{CH}_{2}\right), 120.8$ (Ar-C), 128.1 (Ar-C), 129.6 (Ar-C), 129.7 (Ar-C), 129.9 (Ar-C), 132.3 (Ar-C), $132.8\left(\mathrm{CH}=\mathrm{CH}_{2}\right), 138.1$ (Ar-C), 156.3 (Ar-C), $196.6(\mathrm{C}=\mathrm{O})$.

\section{(E)-2'-(Prop-2-enyloxy)acetophenone oxime $\boldsymbol{E}$-17a}

The ketone 16a $(6.00 \mathrm{~g}, 34.0 \mathrm{mmol})$, hydroxylamine hydrochloride $(2.84 \mathrm{~g}, 40.0 \mathrm{mmol})$ and pyridine $(3.16 \mathrm{~g}, 40.0 \mathrm{~mol})$ were stirred in $\operatorname{EtOH}\left(150 \mathrm{~cm}^{3}\right)$ at $78{ }^{\circ} \mathrm{C}$ for $13 \mathrm{~h}$. The reaction mixture was allowed to cool to room temp., and after standing overnight, the reaction solvent was removed under reduced pressure, leaving a yellow gummy residue which was taken up in $\mathrm{CH}_{2} \mathrm{Cl}_{2}\left(250 \mathrm{~cm}^{3}\right)$, washed with $\mathrm{H}_{2} \mathrm{O}\left(5 \times 200 \mathrm{~cm}^{3}\right)$ and dried $\left(\mathrm{Na}_{2} \mathrm{SO}_{4}\right)$. The organic layer was concentrated to furnish the crude product which solidified upon trituration with pet. spirit $(6.1 \mathrm{~g}, 94 \%) . \delta_{\mathrm{H}} 2.17(\mathrm{~s}, 3 \mathrm{H}, \mathrm{Me}), 4.48\left(\mathrm{~d}, 2 \mathrm{H}, \mathrm{OCH}_{2}\right), 5.25(\mathrm{~m}$, $\left.2 \mathrm{H}, \mathrm{CH}=\mathrm{CH}_{2}\right), 5.95\left(\mathrm{~m}, 1 \mathrm{H}, \mathrm{CH}=\mathrm{CH}_{2}\right), 6.85(\mathrm{~m}, 2 \mathrm{H}, \mathrm{Ar}-\mathrm{H})$, $7.23(\mathrm{~m}, 2 \mathrm{H}, \mathrm{Ar}-\mathrm{H}), 9.35$ (br s, $1 \mathrm{H}, \mathrm{OH}) ; \delta_{\mathrm{C}} 15.5(\mathrm{Me}), 69.2$ $\left(\mathrm{OCH}_{2}\right), \quad 117.3 \quad\left(\mathrm{CH}=\mathrm{CH}_{2}\right), \quad 133.5 \quad\left(\mathrm{CH}=\mathrm{CH}_{2}\right), \quad 154.6-112.8$ $(6 \times \mathrm{Ar}-\mathrm{C}), 155.0(\mathrm{C}=\mathrm{N})$.

\section{2 '-(Prop-2-enyloxy)benzophenone oxime $\boldsymbol{Z}$-17b and $\boldsymbol{E}$-17b}

The ketone 16b (4.45 g, $20 \mathrm{mmol})$, hydroxylamine hydrochloride $(1.67 \mathrm{~g}, 24 \mathrm{mmol})$ and pyridine $(5.56 \mathrm{~g}, 70 \mathrm{mmol})$ were stirred in EtOH $\left(150 \mathrm{~cm}^{3}\right)$ at reflux for $16 \mathrm{~h}$. The reaction mixture was cooled to room temp., and left to stand overnight. The solvent was removed under reduced pressure leaving a yellow viscous oil which was taken up in $\mathrm{CH}_{2} \mathrm{Cl}_{2}\left(150 \mathrm{~cm}^{3}\right)$ and transferred to a separating funnel. The organic layer was washed with $\mathrm{H}_{2} \mathrm{O}\left(5 \times 100 \mathrm{~cm}^{3}\right)$, dried $\left(\mathrm{Na}_{2} \mathrm{SO}_{4}\right)$ and concentrated to yield the isomeric oximes which were purified by flash chromatography $\left(\mathrm{Et}_{2} \mathrm{O}\right.$ : pet. spirit, $\left.1: 6\right)$ and recrystallized to give the syn-isomer $Z$-17b as colourless rods (3.55 g, 70\%) and the antiisomer $E-17 b$ as colourless cubic crystals $(1.05 \mathrm{~g}, 21 \%) . Z-17 \mathbf{b}$ : $\delta_{\mathrm{H}} 4.47\left(\mathrm{~d}, 2 \mathrm{H}, \mathrm{OCH}_{2}\right), 5.12\left(\mathrm{~m}, 2 \mathrm{H}, \mathrm{CH}=\mathrm{CH}_{2}\right), 5.77(\mathrm{~m}, 1 \mathrm{H}$, $\left.\mathrm{CH}=\mathrm{CH}_{2}\right), 7.47-6.97(5 \times \mathrm{m}, 9 \times \mathrm{Ar}-\mathrm{H}), 9.54($ br s, $1 \mathrm{H}, \mathrm{OH})$; $\delta_{\mathrm{C}} 69.1\left(\mathrm{OCH}_{2}\right), 112.9\left(\mathrm{CH}=\mathrm{CH}_{2}\right), 135.8\left(\mathrm{CH}=\mathrm{CH}_{2}\right), 156.0$ $116.7(9 \times \mathrm{Ar}-\mathrm{C}), 155.7(\mathrm{C}=\mathrm{N}) \cdot E-17 \mathbf{b}: \delta_{\mathrm{H}} 4.29\left(\mathrm{~d}, 2 \mathrm{H}, \mathrm{OCH}_{2}\right)$, $5.05\left(\mathrm{~m}, 2 \mathrm{H}, \mathrm{CH}=\mathrm{CH}_{2}\right), 5.60\left(\mathrm{~m}, 1 \mathrm{H}, \mathrm{CH}=\mathrm{CH}_{2}\right), 7.53-6.83$ $(5 \times \mathrm{m}, 9 \times \mathrm{Ar}-\mathrm{H}), 10.10($ br s, $1 \mathrm{H}, \mathrm{OH}) ; \delta_{\mathrm{C}} 70.3\left(\mathrm{OCH}_{2}\right), 112.1$ $\left(\mathrm{CH}=\mathrm{CH}_{2}\right), 135.6\left(\mathrm{CH}=\mathrm{CH}_{2}\right), 158.2-116.4(9 \times \mathrm{Ar}-\mathrm{C}), 158.6$ $(\mathrm{C}=\mathrm{N})$.

\section{2,3-Dihydro-3,5-dimethyl-1,4-benzoxazepine $\mathrm{N}$-oxide 18a}

A solution of the oxime $E-17 \mathrm{a}(1.43 \mathrm{~g}, 7.50 \mathrm{mmol})$ in xylene $\left(225 \mathrm{~cm}^{3}\right)$ was heated at $140{ }^{\circ} \mathrm{C}$ under an atmosphere of nitrogen for $14 \mathrm{~h}$. The reaction mixture was cooled to room temp., and the solvent was removed under reduced pressure $\left(100{ }^{\circ} \mathrm{C}\right.$, $0.6 \mathrm{mmHg}$ ) to give the crude product 18a as a highly viscous orange oil. The pure product was obtained as a yellow oil following fractional distillation $(1.4 \mathrm{~g}, 98 \%) . \delta_{\mathrm{H}} 1.33\left(\mathrm{~d}, 3 \mathrm{H}, \mathrm{Me}^{3}\right.$, $J$ 5.86), $2.43\left(\mathrm{~s}, 3 \mathrm{H}, \mathrm{Me}^{5}\right), 4.56-4.40\left(\mathrm{~m}, 3 \mathrm{H}, \mathrm{H}^{2 \mathrm{~A}}, \mathrm{H}^{2 \mathrm{~B}}\right.$ and $\left.\mathrm{H}^{3}\right)$, 7.32-7.02 $(3 \times \mathrm{m}, 4 \mathrm{H}$, Ar-H $) ; \delta_{\mathrm{C}} 10.9\left(\mathrm{Me}^{3}\right), 17.4\left(\mathrm{Me}^{5}\right), 62.8$ $\left(\mathrm{C}^{2}\right), 79.1\left(\mathrm{C}^{3}\right), 141.3-120.8(6 \times \mathrm{Ar}-\mathrm{C}), 154.0\left(\mathrm{C}^{5}, \mathrm{C}=\mathrm{N}\right)$.

\section{2,3-Dihydro-3-methyl-5-phenyl-1,4-benzoxazepine $\boldsymbol{N}$-oxide $\mathbf{1 8 b}$}

A solution of freshly recrystallized oxime $E-\mathbf{1 7 b}(0.90 \mathrm{~g}, 3.6$ $\mathrm{mmol})$ was stirred in xylene $\left(300 \mathrm{~cm}^{3}\right)$ at reflux under an atmosphere of nitrogen for $5 \mathrm{~h}$ in the presence of hydroquinone $(1 \%$ w/v). The reaction mixture was cooled to room temp., and the solvent was removed under reduced pressure. The crude products were purified by flash chromatography $\left(\mathrm{Et}_{2} \mathrm{O}:\right.$ pet. spirit, $1: 9)$ to give the unchanged oxime $(\mathbf{1 7 b}, 0.02 \mathrm{~g}, 2 \%)$ and the dipole $\mathbf{1 8 b}$, a yellow gum which was triturated from pet. spirit and crystallized to give colourless needles of the title compound $(0.83 \mathrm{~g}, 92 \%) . \delta_{\mathrm{H}} 1.43(\mathrm{~d}, 3 \mathrm{H}, \mathrm{Me}, J 6.60), 4.43\left(\mathrm{dd}, 1 \mathrm{H}, \mathrm{H}^{2 \mathrm{~B}}\right.$, $\left.J_{2 \mathrm{~B}, 2 \mathrm{~A}} 10.26, J_{2 \mathrm{~B}, 3} 2.93\right), 4.47\left(\mathrm{~m}, 1 \mathrm{H}, \mathrm{H}^{3}\right), 4.72\left(\mathrm{dd}, 1 \mathrm{H}, \mathrm{H}^{2 \mathrm{~A}}\right.$, $\left.J_{2 \mathrm{~A}, 3} 10.99, J_{2 \mathrm{~A}, 2 \mathrm{~B}} 10.26\right), 7.37-6.98(2 \times \mathrm{m}, 7 \mathrm{H}, \mathrm{Ar}-\mathrm{H}), 7.60$ $7.81(\mathrm{~m}, 2 \mathrm{H}, \mathrm{ArH}) ; \delta_{\mathrm{C}} 11.8(\mathrm{Me}), 64.3\left(\mathrm{C}^{2}\right), 81.1\left(\mathrm{C}^{3}\right), 142.9$ $121.8(10 \times$ Ar-C $), 155.6(\mathrm{C}=\mathrm{N})$.

\section{$\left(3 \mathrm{a} S^{*}, 9 \mathrm{~b} S^{*}\right)-9 \mathrm{~b}-P h e n y l-1,3 \mathrm{a}, 4,9 \mathrm{~b}-$ tetrahydro-3H-benzofuro- \\ [4,3-c]isoxazole 19b}

A solution of the oxime $Z-17 \mathbf{b}(1.04 \mathrm{~g}, 4.11 \mathrm{mmol})$ in refluxing xylene $\left(350 \mathrm{~cm}^{3}\right)$ was stirred under an atmosphere of nitrogen for $50 \mathrm{~h}$ in the presence of hydroquinone $(1 \% \mathrm{w} / \mathrm{v})$. The reaction mixture was cooled to room temp., and the solvent was removed under reduced pressure. The crude products were purified by flash chromatography $\left(\mathrm{Et}_{2} \mathrm{O}\right.$ : pet. spirit, $\left.1: 1\right)$ to give the ketone $16 \mathbf{b}(0.12 \mathrm{~g}, 12 \%)$ as a viscous pale yellow oil, unchanged oxime $Z$-17b $(0.26 \mathrm{~g}, 25 \%)$, and the cycloadduct 19 as a yellow gum which solidified upon trituration and gave colourless cubic crystals from benzene-pet. spirit $(0.6 \mathrm{~g}, 58 \%) . \delta_{\mathrm{H}} 3.14\left(\mathrm{~m}, 1 \mathrm{H}, \mathrm{H}^{3 \mathrm{a}}\right)$, $3.78\left(\mathrm{dd}, 1 \mathrm{H}, \mathrm{H}^{4 \mathrm{~A}}, J_{4 \mathrm{~A}, 4 \mathrm{~B}} 8.06, J_{4 \mathrm{~A}, 3 \mathrm{a}} 5.13\right), 3.95\left(\mathrm{dd}, 1 \mathrm{H}, \mathrm{H}^{3 \mathrm{~A}}\right.$, $\left.J_{3 \mathrm{~A}, 3 \mathrm{~B}} 11.73, J_{3 \mathrm{~A}, 3 \mathrm{a}} 9.52\right), 4.17\left(\mathrm{dd}, 1 \mathrm{H}, \mathrm{H}^{4 \mathrm{~B}}, J_{4 \mathrm{~B}, 4 \mathrm{~A}} 8.06, J_{4 \mathrm{~B}, 3 \mathrm{a}}\right.$ 7.33), $4.32\left(\mathrm{dd}, 1 \mathrm{H}, \mathrm{H}^{3 \mathrm{~B}}, J_{3 \mathrm{~B}, 3 \mathrm{~A}} 11.72, J_{3 \mathrm{~B}, 3 \mathrm{a}} 4.40\right), 5.61$ (br s, $1 \mathrm{H}$, $\mathrm{NH}), 7.00-6.82(2 \times \mathrm{m}, 3 \mathrm{H}, \mathrm{Ar}-\mathrm{H}), 7.35-6.82(3 \times \mathrm{m}, 4 \mathrm{H}$, Ar-H), $7.49\left(\mathrm{~m}, 2 \mathrm{H}, o-\mathrm{Ar}^{9 \mathrm{~b}}-\mathrm{H}\right) ; \delta_{\mathrm{C}} 50.1\left(\mathrm{C}^{3 \mathrm{a}}\right), 67.3$ and $66.0\left(\mathrm{C}^{3}\right.$ and $\left.\mathrm{C}^{4}\right), 72.4\left(\mathrm{C}^{9 b}\right), 145.1-117.3(10 \times \mathrm{Ar}-\mathrm{C})$. NOEDS experimental results indicate $c i s$ stereochemistry at the ring junction; irradiation of $\mathrm{H}^{3 \mathrm{a}}$ caused a $4.2 \%$ enhancement on the cross ring ArH.

\section{Acknowledgements}

We thank University College, Galway for support of this work and Cork County VEC and Eolas for a student grant (C. O’M.).

\section{References}

1 J. J. Tufariello, in 1,3-Dipolar Cycloaddition Chemistry, ed. A. Padwa, Wiley, New York, 1984, vol. 2, p. 83; P. N. Confalone and E. M. Huie, Org. React., Wiley, New York, 1988, 36, 1.

2 S.-I. Murahashi, H. Mutsui, T. Shiota, T. Tsuda and S. Watanabe, J. Org. Chem., 1990, 55, 1736

3 J. Hammer and A. Macaluso, Chem. Rev., 1964, 64, 473

4 C. O'Mahony and F. Heaney, Chem. Commun., 1996, 167.

5 (a) R. Grigg, F. Heaney, J. Markandu, S. Surendrakumar, M. Thornton-Pett and W. J. Warnock, Tetrahedron, 1991, 47, 4007; (b) R. Grigg, J. Markandu, T. Perrior, S. Surendrakumar and W. J. Warnock, ibid, 1992, 48, 6929; (c) A. Hassner, R. Maurya, A. Padwa and W. H. Bullock, J. Org. Chem., 1991, 56, 2775; (d) A. Hassner, K. M. Lokanatha Rai and W. Dehaen, Synth. Commun., 1994, 24, 1669; (e) M. Gotoh, T. Mizui, B. Sun, K. Hirayama and M. Noguchi, J. Chem. Soc., Perkin Trans. 1, 1995, 1857; ( $f$ ) T. Shimizu, Y. Hayashi and K. Teramura, Bull. Chem. Soc. Jpn., 1985, 58, 397; ( $g$ ) W. Oppolzer and K. Kekker, Tetrahedron Lett., 1970, 1117; (h) M. Gotoh, B. Sun, K. Hirayama and M. Noguchi, 
Tetrahedron, 1996, 52, 887; (i) M. H. Norman and C. H. Heathcock, J. Org. Chem., 1987, 52, 226.

6 (a) R. Grigg, J. Markandu, S. Surendrakumar, M. Thornton-Pett and W. J. Warnock, Tetrahedron, 1992, 48, 10 399; (b) R. Bishop, P. R. Brooks and S. C. Hawkins, Synthesis, 1988, 997; (c) R. Grigg, T. R. Perrior, G. J. Sexton, S. Surendrakumar and T. Suzuki, J. Chem. Soc., Chem. Commun., 1993, 372.

7 (a) M. E. Fox, A. B. Holmes, I. T. Forbes and M. Thompson, J. Chem. Soc., Perkin Trans. 1, 1994, 3379 and references cited therein; (b) E. Ciganek, J. M. Read Jr. and J. C. Calabrese, J. Org. Chem., 1995, 60, 5795; (c) E. Ciganek, ibid, 1995, 60, 5803.

8 M. Rouillard, Y. Girault, M. Decouzon and M. Azzaro, Org. Magn. Res., 1983, 21, 357.

9 J. Jirman, A. Lycka and M. Ludwig, Collect. Czech. Chem. Commun., 1990, 55, 136.

10 R. R. Fraser and M. Bresse, Can. J. Chem., 1983, 61, 576.

11 D. H. R. Barton and J. M. Beaton, J. Am. Chem. Soc., 1961, 83, 4083; P. Baas and H. Cerfontain, J. Chem. Soc., Perkin Trans. 2, $1979,156$.

12 N. Katagiri, H. Sato, A. Kurimoto, M. Okada, A. Yamada and C. Kaneko, J. Org. Chem., 1994, 59, 8101.

13 (a) M. Tiecco, L. Testeferri, M. Tingoli and F. Marini, J. Chem. Soc., Chem. Commun., 1994, 221; (b) M. Noguchi, T. Mizukoshi,
T. Uchida and Y. Kuroki, Tetrahedron, 1996, 52, 13 097; (c) A. S. C. Chan, C.-C. Chen, C.-W. Lin, Y.-C. Lin and M.-C. Cheng. J. Chem. Soc., Chem. Commun., 1995, 1767; (d) J. F. Hansen and B. H. Novak, J. Heterocycl. Chem., 1994, 105; (e) C. G. McCarty, in The Chemistry of the Carbon-Nitrogen Double Bond, ed. S. Patai, Interscience, New York, 1970; $(f)$ M. Anzini, A. Garofalo and S. Vomero, Heterocycles, 1989, 29, 1477.

14 J. E. Baldwin, J. Chem. Soc., Chem. Commun., 1976, 734.

15 P. G. Sammes and D. J. Weller, Synthesis, 1995, 1205; B. S. Oriek, P. G. Sammes and D. J. Weller, J. Chem. Soc., Chem. Commun., 1993, 1412; B. S. Oriek, P. G. Sammes and D. J. Weller, Tetrahedron, 1993, 49, 8179 .

16 A. Alberti, G. Barbaro, A. Battaglia and M. Guerra, J. Org. Chem., 1981, 46, 742; M. Lucarini, G. F. Pedulli and A. Alberti, J. Org. Chem., 1994, 59, 1980.

17 M. M. Miland and R. W. Koops, J. Org. Chem., 1990, 55, 5058.

18 P. Armstrong, R. Grigg, F. Heaney, S. Surendrakumar and W. J. Warnock, Tetrahedron, 1991, 47, 4495.

Paper 7/04315E

Received 19th June 1997 Accepted 25th September 1997 